\title{
Congregational anAlysis: A theological AND MiNisterial APPROACH
}

\section{Author:}

Malan $\mathrm{Nel}^{1}$

\section{Affiliation:}

${ }^{1}$ Centre for Contextual

Ministry, University of

Pretoria, South Africa

\section{Correspondence to:}

Malan Nel

e-mail:

malan.nel@up.ac.za

\section{Postal address:}

Centre for Contextual

Ministry, Faculty of

Theology, University

of Pretoria, Lynnwood

Road, 0083 Hatfield, South

Africa

\section{Keywords:}

congregational analysis;

faith communities;

minister; ministry;

congregational identity

\section{Dates:}

Received: 28 June 2009

Accepted: 28 July 2009

Published: 05 Nov. 2009

How to cite this article:

Nel, M., 2009,

'Congregational analysis:

A theological and

ministerial approach',

HTS Teologiese Studies/

Theological Studies 65(1),

Art. \#303, 17 pages. DOI:

10.4102/hts.v65i1.303

\section{This article is available}

at:

http://www.hts.org.za
(C) 2009. The Authors. Licensee: OpenJournals Publishing. This work is licensed under the Creative Commons

Attribution License.

\section{ABSTRACT}

The research problem concerned is: What criteria should be used when congregations are analysed? Congregations as faith communities are defined differently. Identifying the local congregation as a defined and as an empirical subject plays a major role in answering the research question. The theological points of departure taken are that any measure of a local congregation has to deal with issues such as faithfulness to the gospel and the missional identity and integrity of the congregation as a contextual faith community. The hypothesis is that theologically informed and motivated congregations can and should be analysed in the process of continuing reformation. While the first article described the approach and outcome of empirical research, this article focuses mainly on understanding the church as intermediary in its ministerial role-fulfilment. Ministries are modes by which God is coming to his own and through them to his world. Eventually a case is made for congregational analysis as a test of faithfulness to this understanding of ministry.

\section{INTRODUCTION}

It is abundantly clear from any literature study that congregational analyses are important for many reasons. It helps to get the bigger picture of, say, a denomination or 'the church' in a region or country, as in the works of Ammermann (2005), Barna (2002), Carroll (2000), Dudley and Ammermann (2002) and Schaller (2001). It is also important in the basic sense of the word 'analysis' as an investigation of the component parts of the whole. In this sense I have described it (Nel 1994; 2005a). The same is true for much of the research I refer to above and in a previous article (Nel 2009a).

The research purpose in this and the previous article is to discern a way of approaching and undertaking a congregational analysis that is both faithful to the identity of the congregation and has scientific integrity. The last mentioned does not just mean being statistically sound but being empirically well tested. It is research being put out there after more than 1000 congregations have been analysed and consulted, as in the cases of Callahan (1987), Schaller (2001) and Schwarz (1996).

This article on revisiting congregational analysis is

- an attempt to take seriously the missional identity of the congregation; as well as

- the critical role of ministry as congregational role-fulfilment, in developing an instrument for congregational analysis.

The hypothesis of this article (and the previous one [Nel 2009a]) is that congregational analysis not only can be, but should be done. However, the theological identity of congregations not only impacts on, but in more than one way also determines when and how they are analysed;

- the theological and empirical identity of congregations informs the need for and the content of the analysis (approach, methods and content); and

- the theological and empirical identity determines the kind of process and the outcomes of the analysis (strategies).

\section{MISSIONAL IDENTITY AND FAITHFULNESS}

\section{The critical importance of identity}

The identity of the local church plays a major and determining role in the understanding and process of building up or developing missional congregations. I used the word and concept 'identity' 137 times in my book Gemeentebou (Nel 1994). The 2005 English translation was even published under the title Who are we? Understanding and finding identity in the local church.

Hardly any book is now published without the 'who are we?' question. Tucker (1982:1) was one of the first to use it as the title of the first chapter of his book on church planning questionnaires - referring to an older publication by Howe in which a story, shared by Dick Foster, was quoted:

It was about a wealthy man who had been lost in a forest. He was almost at the point of desperation when a forest ranger found him. As they met the ranger asked a strange question, "Who are you sir, and where are you going?" The man was so relieved to be found, and so impressed by the ranger's question, that he offered him a job which the ranger could not afford to turn down. As a part of the ranger's responsibility, he was to ask his employer, every day, the question of the forest, "Who are you sir, and where are you going?"

(Howe 1959:17)

Today these same words are often used in the discussion of the missional identity of the church. In a fairly recent South African publication concerning congregational studies in Africa, Hendriks (2004:105106), in a chapter he entitles 'Identity analysis', writes that 'the question a congregation should ask constantly is: "Who am I and what is my purpose in life?"' Knowing who we are and discerning where we are going are purposeful, earnest and conscientious theological activities. 


\section{Understanding of missional identity has changed}

The missional identity of the church was argued long before the gospel and culture movement or the emerging church movement, even before Hoekendijk, although he played an important role in the rediscovery of the notion. It might be fair to say that Kraemer in more than one way prompted the debate and movement. It was especially his book on the Theology of the laity (Kraemer 1958) that caught the attention. Hoekendijk simply did not live long enough to survive the onslaught of Christendom on his theology and thinking about the church as we now do. He argues that

... the call to evangelism is often little else than a call to restore 'Christendom', the Corpus Christianum, as solid, well-integrated cultural complex, directed and dominated by the church. And the sense or urgency is often nothing but a nervous feeling of insecurity, with the established church endangered; a flurried activity to save the remnants of a time now irrevocably past.

(Hoekendijk 1966:15)

His criticism of the church is probably, at least partly, due to these tendencies in cases where churches were involved in reaching the world. He says that 'Evangelism and churchification are not identical, and very often they are each other's bitterest enemies' (Hoekendijk 1966:25). He rather calls the 'church' a

Christian community ... this fellowship of the partakers of the same salvation, a company of strangers and pilgrims, paroikia, or a group of sojourners in the world, fully detached and therefore free to relate itself to every form of existence... The koinonia is the place where the shalom is already lived.

(Hoekendijk 1966:29)

In context, he means seekers of the Kingdom of God (Hoekendijk 1966:25-31; also see Hoekendijk 1948:237, 278, where he writes that "The congregation (as a whole) is the evangelism-unit, who focuses herself with her message on the needs of her society and who translates this message in practical service') (freely translated from the Dutch - MN). He quotes Barth who refers to the exemplary existence of the congregation and therefore sets up a token of the coming Kingdom.

Callahan (1983:xii) already used the concept 'missional'. Armstrong (1979:38-50) argues the very same issue and states that the church is the evangelist. The last mentioned expression was then already the title of a book by George Sweazey, The church as evangelist (1978).

For many years the church was 'on top of it' in nations around the world. But this changed, maybe forever and for the good. Guder and others (Guder 1998:48-55) describe this process of 'disestablishment' (Guder 1998:50) of the Christendom paradigm. The process is still in progress. When churches are under pressure of the changes in society, when identity becomes vague, churches are tempted to give in to 'the ecclesial structural sin' ('zur ekklesiogenen strukturellen Sünde'): Institutional problems become more serious than the problem of evangelism' (Fuchs 2001:43). Fuchs (2001:46-77) continues to outline the identity of a church willing to follow the Christ and seek the Kingdom of God in terms of the modi of diakonia, martyria, koinonia, liturgy and pastoral care. Bullard (2006:vii, 6-21) invites churches to develop 'vision plus intentionality' - the intentionality to understand and develop their 'full Kingdom potential'. In missional thinking 'seeking the Kingdom of God' is as much a mark of a true church as anyone of the other well-known reformed marks of the church.

\section{Identity finding: A challenge}

Identity finding remains a challenge for congregations, whether Christendom is still very much alive or whether the process of disestablishment is fairly done with. We are indeed challenged to understand our identity as both 'a way of life' and 'a system of belief', as McLaren (2008:3-8) introduces his book Finding our way again (the two expressions are a quote from an interview he had with P. Senge). Describing our identity is becoming increasingly difficult. The church in emerging culture (Sweet
2003) is more than the title of a book. This is reality. The jury is still out on how we perceive this reality to be. The great essay in this book by a young theologian, Michael Horton (Sweet 2003:105-138), on postmodernism and the emerging church is worth every moment of reading time. Several of the other authors such as McLaren and McManus interact with Horton on his viewpoints. Horton's analysis of the current culture is very critical and in a good spirit also challenging, as his co-authors admit. He is arguing that we have gone into a mode of almost 'fatalism' and have bought into many arguable issues such as marketing and the will of the audience. He shares his doubts about learning through icons, the overestimation of experience, and other current trends in the emerging world and church. In his rejoinder he responds to a remark by McLaren and says that much of what is advertised as postmodern today is in fact 'mostmodern': 'Autonomous individualism, an insatiable appetite for innovation, suspicion of the past, and other marks of modernity persist in a more radical form in much of postmodern discourse (Sweet 2003:133). I am referring to this to offer but one argument as to why it is even more difficult today to say 'who we are' than it may have been yesterday. Some of McLaren's books even point in their titles (and more so in content) to this dilemma. The subtitle of the 2003 book by McLaren and Campolo is a good example: How the culture-controlled church neutered the gospel. This is another good example that understanding and naming identity is evenly difficult where Christendom is still alive (culturedominated churches) as where the emerging culture and, maybe sometimes, the emerging church ignores the 'church'. McLaren's book (2004) entitled A generous or+hodoxy is a great example of how complex this issue has become. When the church is what it so often empirically is and has been, it is difficult to recognise the Triune God in that kind of church. Several of the 'Why I am ...' chapters point to this dilemma: 'Why I am post/Protestant; fundamentalist/Calvinist; (Ana)baptist/Anglican'. My brief reference is not to evaluate the book. That asks for another article. The point I am trying to make is that it is becoming increasingly difficult to say who we are. I may even be labelled modern in my attempt to 'describe or define' identity.

Snyder and Runyon (2002:35) call the church 'a complex organism'. Immink and De Roest (2003:7) also acknowledge this with the Dutch context in mind. They state that they see the identity of the faith community as a 'dynamic happening' (gebeure). Church praxis is 'taking place in a continuing dynamic relationship with society and culture' (freely translated from the Dutch - MN)

However challenging, it is nonetheless critical. Dick, in his most recent research says that

of all the stability criteria, a strong sense of identity - who we are as a congregation of God's people - is perhaps the most important. "Who are we?" rests at the heart of our entire walk of faith. Individually, we wrestle with this question on a regular basis, but it is every bit as important that we wrestle with it corporately as well.

(Dick 2007:17)

Churches that are rediscovering themselves (retrogressive in Dick's terminology) have an incredible strong sense of identity (Dick 2007:69). This is the most obvious difference of vital churches: 'We' is the word spoken most frequently in vital congregations (Dick 2007:92). Mann (1999:9) says that the first thing done by 'courageous congregations facing serious decline, attempting the difficult path of redevelopment' was 'recognizing the death of the congregation's previous identity and purpose'. Reformation starts with the rediscovering and understanding of identity ( $c f$. Nel 1994:125-147; 2005a:150-175). Mann urges churches to continuously go back to this identity search:

No strategy, structure, or program will make much difference in the long term viability of your church unless you go back to the fundamental question: How will we connect our deepest faithidentity to the realities of our context today?

(Mann 1999:98) 
Identity is about the 'we' who 'are here now' (cf. Keifert 2006:22). To play a little with the expression, Keifert (2006:22) uses as the title to his book: We are here now.

Easum (2001) argues for leadership to take the first and sometimes drastic move to unfreeze a stuck situation. He reacts against the 'traditional' approach of unfreezing. Too often such an approach 'refreezes the organization' (Easum 2001:63; cf. his diagram by which he explains 'finding the appropriate Unfreezing Move' [Easum 2001:66] $)^{1}$. While we do not differ in totality, my preference is towards a more theologically motivated departure point in unfreezing congregations. Leadership is important in the process of unfreezing. Ultimately, however, finding identity unfreezes a congregation. I called the first phase in the process of reforming (building) a missional church: 'motivation, unfreezing and mission development' (Nel 2005a:147). Easum (2001:63) is however right in pointing out that many top-down approaches to bring about change 'worked well in the slow, evolutionary past. But is a recipe for failure in the present world of rapid change and discontinuity'. The mark of faithfulness is no longer how well a church

supports the denomination, or how long it can survive, or how many members it receives, or whether it is healthy, or even how harmonious it is. Rather we gauge faithfulness by a congregation's willingness to follow Jesus into the mission field.

(Easum 2001:27)

The point of departure taken in finding missional identity is that this comes from the inside, it is intrinsic motivation, theologically informed, not made by leaders, however important leadership in the process might be. Finding identity is therefore not just a challenge, not just complex; it is often painful. The return of new life is often painful.

\section{A personal remark}

In the article on empirical approaches to congregational analysis (Nel 2009a), I stated my choice to help reform mainline and other congregations. This is difficult. It is probably easier to start afresh than to work for the reformation of the empirical congregation anywhere in this world. Schwarz (1999:7) says, rightly so, that 'every reformation movement is confronted with an opposing force known as "orthodoxy"'. It is also being made difficult by independentism, by de facto congregationalism (Warner 1994:54-99) whether inside or outside of denominations. Every reformer is, for a time at least, called a heretic. The 16th century reformation is one good example. The history is proof of how easy it is to deform and how difficult it is to reform deformed churches. Campolo (1995) writes from the viewpoint that mainline churches can reform, but chooses a fitting title with a question mark: Can mainline churches make a comeback? Chesnut (2000) tells the beautiful story of the reform of a mainline congregation. Carroll (2000) titled his book Mainline to the future. I edited the stories of hope in 17 mainline congregations and stated that there are many more similar but untold stories of hope (Nel 2006:8). It is easy to give up on mainline congregations, yet it is worth never giving up on them. It is possible to change a church without destroying it (cf. Malphurs 1993). This article is about finding a way to analyse with the purpose to reform any given congregation - for the sake of the glory of God and the fulfilment of his Kingdom plan for church and world. It is sometimes just too easy to walk away from the body and rationalise your walking away in whatever clever way. I have many good friends in independent churches. My point is not to argue or question the existence of those congregations. I would even, up to a point, agree with McLaren (2008:128) when he answers the question 'Do we work for reformation and renewal on the one hand, or for revolution and refounding on the other?' My answer, as might be expected, is 'both'.

1.For a similar diagram, see Eickhoff (1992.291) and his closing paragraph to the chapter (1992:309). 'Ein klares Konzept zu erarbeten macht Mune. Die Muhe aber lohnt sich. Gemeindeleltung und Gemeindebegleiter haben Klarheit gewonnen über Sinn, Ziel und Plan, über Wege und einzelne Schritte für die Gemeindeentwicklung Das Klare Konzept verhilft zu einer verantwortlichen Praxis
We are often disappointed in the church. McLaren writes, with almost obvious pain, how he grew up loving the church and then had to discover the illness of the church as an inviting community.

I want to welcome them in, to help them become part of our life and mission. But often I have felt like an ambulance driver bringing injured people to a hospital where there's an epidemic spreading among the patients and doctors and nurses ... You try to help the hospital get the epidemic under control again, so they can get back to helping people heal ... The hospital can be a pretty sick place sometimes.

(McLaren 2004:21)

What I want to do in this section is to declare my choice. However painful and difficult, the reformation of any faith community is a possibility, a God-given possibility. I have explained my preference for the concept reformation elsewhere (Nel 2005a:363366), but acknowledge and respect the other concepts used, such as renewal (Snyder 1996; 2005), revitalisation (Avery 2002; Gibbs 1993), redevelopment (cf. Mann 1999:1-12;) and a second resurrection (Easum 2007). I agree with Schaller (2003:14-15):

$[M]$ ost of us believe that our denomination is filled with a quantity of assets ... each one of the seven largest of what often are lumped together as "the old mainline Protestant denominations in America" is larger in members and worshippers than $90 \%$ of all organized religious bodies in the United States that have a national headquarters. Each one represents a huge quantity of accumulated resources.

(Schaller 2004:21)

Faithfulness to identity in my mind does not mean to hang on to the mundane and ordinary or for a church merely to hang on as if God gave his life in Christ so that we could be ordinary and mundane' (Easum 2007:97-98). I think Easum (2007:98) is right when he states that mainline churches often seem to have this problem. What I argue for is to be faithful to our theological understanding of being a reformed and reforming living organism.

Numerical growth is not the only sign of reformation either. While some would feel comfortable with such an understanding, I feel more comfortable with Roxburgh's (1979:20) description that God is certainly not a 'legitimating footnote of ecclesiology'. He argues against numerical growth being 'the talisman of ecclesiological health and technique the primary method for re-establishing the church's place in the culture' (also cited by Sjogren 2002:15).

I confess that in essence the congregation is an expression of God's love for the world. Congregations are indeed his chosen vehicles to the world, in any given context. They are his gift to their context. They are God's search parties for the lost and the broken, the victims of the accidents in life. To be and to stay roadworthy vehicles, to stay gifts whose shelf life date is still valid, search parties who are well prepared for every possible emergency, congregations need one another. Presbyteries, synods, dioceses, districts (or whatever these family meetings are called) are but confessional consciences and, in the meaning of the metaphor of the vehicle, repair shops - helping one another stay roadworthy and faithful vehicles of God's grace in Christ and through the Spirit. Campolo (1995:192-193) uses the strong word 'embrace' in his reference to this: 'Presbyteries embrace the churches of a given region ... as a synod embraces all the presbyteries of a geographical region'.

\section{THEOLOGICAL MARKERS AND CONCEPTUAL CLARIFICATION}

\section{What are congregations about?}

What exactly are congregations about? Why are they around and why should they be? Who will miss them when they are no longer in communities? If they will be missed, what will they be missed for? And why can other institutions not take their places? 
This is what a practical theological and a missional perspective on ecclesiology is about; asking the what, why and how questions. I believe this part of the article could also have been called a brief ecclessiological 'verantwortung'. This is becoming increasingly difficult. The day that academic ecclesiologies and denominational ecclesiologies determined the local congregation is, at least for the time being, gone (cf. Dekker 2000:19-36, who thinks that it is almost no longer possible). I do not mean this entirely negatively. With Carroll (2000:xii) I believe this might be positive. Ecclesiology often originates at the local level. Carroll even calls it 'local ecclesiologies, ecclesial practices to what Robert Schreiter (1985) called "local theologies"'. Carroll (2000:xii) defines local ecclesiologies as 'organizational forms and practices through which local congregations attempt to give expression to the gospel and received ecclesial traditions in ways appropriate to their local social and cultural contexts'.

These developments can also be negative. It has led, and will probably continue to do so, to what Warner (1994:54-99) calls 'de facto congregationalism'. Carroll (2000:1) takes his point of departure from a saying by Barth (1962:739), namely that 'there has never been anywhere ... an intrinsically sacred sociology [of the church]'.

Carroll's (2000:2-25) diagnosis of how (and why) this radical change from traditional denominational to local ecclesiology has taken place is indeed enlightening and helpful in unpacking the research problem in this article. He follows the line developed by the historian Holifield (1994:23-53) who traced the history of American congregational models and identified four such types: comprehensive congregations (one congregation per community); devotional congregations, which was dominant until after the civil war and helped by the impact of the Great Awakening; social congregations, catering for the social needs of the community; and participatory congregations, which show a lot of resemblance to the social but cater for the diverse needs of a society of 'the picking and the choosing'. Carroll's (2000:525) description of what he calls the posttraditional ${ }^{2}$ society (or the process of 'de-traditionalisation' [Heelas, Lash \& Morris 1996]) is helpful to understand the almost unending variety and diversity in the congregational landscape. Admitting that the process of secularisation no longer explains the total picture of change and church derailments, he offers this broader term of posttraditional. Carroll even prefers the term over postmodern (2000:9) because the term 'postmodern' itself (like secularisation) has become ideologically loaded. He admits that we may not be completely posttraditional but are experiencing serious 'detraditionalisation'. Carroll (2000:10, 16-17) basically means:

- that something has occurred or is occurring that is transforming previously taken-for-granted social and cultural patterns, including ecclesial traditions

- that '[a]t its heart, then, posttraditional society and detraditionalization are about changing conceptions of authority and truth ... Detraditionalization is a process that involves a shift in authority from something that is "out there" and external to us to authority that resides "in here", in the self, in the authority of our own knowledge and experience as individuals; and

- that 'voice is displaced from established sources, coming to rest with the self' ( $c f$. Heelas et al. 1996:2).

As a result we are now compelled to live

reflexively or reflectively, both personally and, in terms of the focus of the book, ecclesially ... In a detraditionalized world, in contrast, we are confronted daily with a multitude of choices that cause us to live reflexively, constructing our own identities as posttraditional people.

(Carroll 2000:17, 105)

What forces are driving this process? Why are traditions, at least not enough so, it seems, a driving force in congregational

2.cf. Hervieu-Léger, who used the concept in 1993 (when his book was published in French) already as 'post-traditional society and post-traditional religion' (2000:163). life? MacIntyre (1984:263) says that traditions must be socially embodied if they are to be living traditions (cf. Carroll 2000:17). Why are communities no longer those 'institutions of memory' (Hervieu-Léger 2000, as cited by Carroll 2000:18), or as Carroll (2000:18) calls them 'ecosystems for nurturing faith'? Carroll draws upon the findings of the sociologist Bauman (1995:72104) in explaining the phenomenon. Bauman contrasts rather sharply the early pilgrims and social types that characterise a postmodern world. He takes a point of departure in Calvinistic doctrine, which has provided people with a new narrative for their disembedded lives:

a road to travel, a project or purposes in life toward which they moved through the world as sojourners. Postmodern (or posttraditional) life, however, is inhospitable to pilgrims. The hub of postmodern life strategy is not identity building, but avoidance of being fixed.

(Baumann 1995:89)

Bauman (1995:92) then describes four postmodern social types and calls them the 'pilgrim's successors':

- 'strollers' whose lives are a series of aimless episodes

- 'vagabonds' who have no settled place but piece their trajectory together bit by bit

- 'tourists' who, unlike vagabonds, have homes, but nonetheless travel from place to place in search of adventure and excitement without becoming part of the places they visit

- 'players' for whom life is a succession of self-enclosed games, each with its own rules. One plays every game wholeheartedly, as children do, but works to ensure that no game has any lasting consequences (Bauman 1995:99; Carroll 2000:19).

"Today this characterize[s] the majority. Time is no longer experienced as a river that flows from here to there. It is instead "a collection of ponds and pools"'.

(Bauman 1995:91)

If we live in a world, and I believe we do, of local ecclesiologies, what then are the commonalities (if any)? Within posttraditional society, which congregations will still feel themselves connected to other congregations to the extent that it makes a difference in developing and determining their local ecclesiologies? Schwarz and Schwarz (1984:27-52ff) already struggled with this problem and made a choice to work with building up the 'ekklesia' (local church in their book) and leave the 'kirche' (denominational 'Volkskirche') out in the cold.

Should we do this? What are the reasons for not doing it? Is it traditionalism only or does the nature of the church as a theologically defined subject compel us not to let go of academic and denominational ecclesiology ( $c f$. Schippers 1982; 1983; 1987)?

I believe that the nature of the church as a creation of the Triune God does compel us to rethink ecclesiologies as such. However much room we make for local ecclesiologies, this should and does not have to mean absolute congregationalism. The body and its confessional unity, the body and its global intentions, the body and the total faith community play a major role in who we are in any local context. We live in a pluralistic world and ecclesiology has to take that into account. De Reuver (2004) devotes a whole book to his research on the ecclesiological value of plurality. Dekker (2000:109-127, 185-197, 227-229) argues for the concept 'church' (kerk) and even takes up an argument against the concept 'gemeenteopbouw' (building up local churches) because the last mentioned, according to him, localises the church too much. Dekker's (2006:126) 'definition' of the church is very much a sociological one: an institution formed by believers ... ('Door gelovigen gevormde instelling...'). It is true that the focus is on the reformation of the local congregation as Jonkers and Bruinsma-de Beer (2000:18: 'gemeenteopbouw' focuses on the lokale kerklijke gemeente) argue. Or as Schlottoff (1989:7-9) describes the 'Ortsgemeinde' to be the future of the church in 
Germany (cf. Brouwer et al. 2007:144-147). It is, however, not true that the subject field, as it is generally practised, loses sight of the church as a whole.

Not having the space to discuss this, I concede that my conviction and premise is: The congregation is a local expression of the church of Christ in this world. The church has a global and local context (cf. Cameron et al. 2005:43-88).

The few central concepts discussed below are an attempt to give expression to a local ecclesiology that takes theological insights into account. ${ }^{3}$ The congregation is the ultimate expression of what we call church. Only a few of these concepts are touched upon: church, congregation, identity and ministry. A few remarks about these concepts concern the research problem and hypothesis of this article.

\section{Congregation/church}

\section{God's own}

The story and the purpose of humankind precede and inform the story and purpose of the church. The why of man and the why of the church are deeply interwoven. The church is because we humans are. The church is but the new 'we' because the old 'we' failed so dismally. Men and women were supposed to know, love and serve God, the Creator of heaven and earth. They did not and instead made themselves gods, gave them names (knew them), loved them and served them. And God, in history, made sure that there were and always will be men and women who 'know, love and serve' differently: his chosen and different people, his 'qahal', his 'called ones', his congregation. 'God's people are his own possession, his treasure. The church is defined by belonging to God' (Clowney 1995:29; cf. Lv 26:12). The very special way in which Ezekiel (16:1-22) describes God's grace in seeing Israel naked, deserted and then making her his bride, is but one biblical example of this critical value for the being of the church. As God's new creation, the congregation is nothing but his new Adam and Eve. They have always been there and in Christ always will be. God is well prepared for taking his creation forward - the whole of creation. His original purpose is still on track, despite the many hurdles and stumbling blocks in the coming of the Kingdom. The congregation is his plan.

It is important to understand that the congregation never takes over the plan. The plan is God's. The congregation is the plan, God's plan. One might say that this is the/our very reason for existence: to be his plan. God has created himself a showcase of the new creation. Or even better: He has a new way of showing what creation/his world was intended to be all along: the fulfilment of being created to take care (on his behalf) of the whole of creation. The congregation is the continuation of God's plan for the unfolding of the Kingdom come and coming.

\section{The congregation is an in-betweener}

The congregation, in a real missional sense, is about God's coming to this world to be known, loved and served. Even stronger: God has never stopped dealing with the world in a very direct way. He has created himself an 'intermediary pastor' called many different names: people, priests, servants, coworkers, bride, light, salt, body, flock, etc ( $c f$. Minear [2004] for more images). This 'intermediary' is cared for in many different ways. As a matter of fact, as intermediaries they have received and are receiving everything they need to serve his coming to them and to the world. They lack nothing. The Lord is their Shepherd/King and has blessed them with every blessing in heaven and on earth ( $c f$. Ps 23 and Eph 1). They have everything they need to be the plan, the Kingdom plan. This means that the congregation is important and needed, but in another sense very relative (cf. Dekker 2000:111-115). The truth about the church can

3.So many books on ecclesiology are available. Neuner $(1994 ; 1995)$ gives a good oversight of critical ecclesiological issues and confessions right through history, citing the original sources directly (translated into German). Also compare Alston citing the original sources directly (translated into German). Also compare Alston
(1984) for 'guides to the reformed tradition'. For an African perspective, cf. Nyamiti (1984) indeed be found by keeping both poles of this antithesis in mind. I am convinced that in more than one way the emerging church movement is a correction to a Christendom-overestimation of the church and its place in the world ( $c f$. for example McLaren 1998; 2000). Whether this movement is overreacting, only time will tell.

\section{Identity: Calling us names, identifying 'us' by name}

A few of the names he calls his people, his plan, are important for the sake of the research problem at stake. Can and should this 'plan' be analysed? If so, what will inform the process and identify the 'tools' used to analyse the congregation?

\section{A community of faith}

The congregation is a community of faith or, the more often used concept, 'a faith community'. In most theological traditions this refers to a community that came into existence by God's intervention alone. In reformed theology this refers to the Sola Gratia principle: We are because he is a gracious God. The Old Testament reference to the 'Qahal Jahve' already referred to this. This means that our/the congregation's very existence is determined by 'us' taking God seriously. We are because of him and for him, meaning that we are a faith community. We are people who take God very seriously. He himself and his will are the determining factors in and for our existence. In reformed theology this is referred to as the Sola Fide principle. Seeking and discerning his will determines every step of the way and plan. Only and when it is about him is it about us. We 'have' critical relevance because of his relevance. The congregation loves him enough to care about this. We are called disciples of Jesus. Disciples take God very seriously.

\section{A confessing community}

A confessing community ('Bekennende Kirche', cf. for example Ebeling 1998:41-54) is another 'name' that plays an important role in determining an answer to and in our research problem. The 'plan' has everything to do with communicating the good news of a Creator who loves what he has made and is in no way prepared to give up on what he has made. The congregation he gracefully created confesses him and his grace in his world. We make him known for the great God he indeed is. We do that in line with the revealed truth about him. In reformed theology this is referred to as the Sola Scriptura principle. The congregation is therefore serious about who they confess and what they confess about him. Congregations are to be communities who confess what they know about him, why they love and serve him - because we 'know, love and serve' who and what we confess. This makes congregations public communities. Nothing happens in the dark, away from the perceptions of the world where any congregation is.

In this sense, more than in any other way, the congregation is a spiritual reality/being. It is the work of the Holy Spirit to make known the Father and the Son. When he reigns and fills his people they participate fully in what he does. We/the congregation are being employed by God the Spirit into what we were created for and what he came to do: make known the involvement of the Father and the Son in the healing and restoration of this broken reality (cf. Van Ruler 1969:181; 1973:12, 28-29, 36-37).

\section{A servant community}

This 'intermediary pastor' is not only in service of God (and his plan) - the congregation is God's servant. We confess by word and deed who he is and what his plan is. We are here to bring, on his behalf, help and hope to the world (context) we have been given to. We have missional integrity because of our contextual serving (help and hope giving) relevancy. This reality brings into play the modesty of the congregation. The reign never changes hands. We never become rulers. Only the one and only true God is God. However important the congregation is, we 
are but servants, we are the plan. Joubert (2008:44) calls this 'a new status of honor: the slave'. Armstrong (1979:38) has called this the integrity test of the quality of our discipleship. When we forget this and the congregation becomes the 'great issue' itself, we are far away from what we were created for. Hoekendijk (1966:32-46) already pointed to what I call here the relativity of the church in relation to the importance of the coming Kingdom. He stated that 'in history a keen ecclesiological interest has, almost without exception, been a sign of spiritual decadence' (Hoekendijk 1952:325). However central in the coming of God to the world, the congregation just never becomes the centre by and in itself. It is about the balancing of a simultaneity: at the same time relevant and relative. We are but slaves seeking the Kingdom, a bunch of Kingdom-seekers ( $c f$. the older but very good book by Snyder [1977] on the church as 'the community of the King'; and also Heyns's book on the church [1977]).

\section{The body of Christ}

The metaphor of the body of Christ for this 'intermediary pastor' is often used. It even, wrongly so, has been called a 'model' for being church. Models often take away from, rather than add to, the meaning of a metaphor. The metaphor, however, emphasises the importance of the corpus of members in being the plan and making the plan work. The many members are the one functioning body. The unity (oneness) is important in the fulfilment of the plan. Brokenness in the sense of disunity would be detrimental to the plan. As a matter of fact, the world would then not believe the intention and integrity of the plan as being God's (cf. Jn 17).

This metaphor also carries the notion that the congregation is 'together'; is a community. This togetherness has been called the 'basic form' of being the congregation. Firet (1986:85) said 'the act of assembling together as a church is the basic form in which the body of Christ functions'. It is indeed a very vital issue. It goes back to our name qahal/ekklesia. It is, however, not the gathering as such that makes us a congregation. Gathering does not do it in itself. It is being gathered that makes the difference: Israel was an assembly because they gathered before God, appearing in his presence (Dt 4:10). It is his presence, him having called us together, that constitutes our togetherness, our koinonia. The well-known words of Firet (1986:82) express it well:

pastoral role-fulfilment is the intermediary of God's coming in his word. God draws near to us as the God who speaks to us. He reveals his name and in his name he discloses the marvel of his presence and availability. He makes public his truth as present reality. In all this He actualizes his salvation.

(cf. also Nel 2005a:2-10)

\section{A people cared for}

Many metaphors (one may even say most of them) point to the identity/being of the congregation in the sense of a people being cared for. Some metaphors point to both cared for and planned to be like the body, the priest, the servant, the bride, etc. The importance of the 'cared for' metaphors is that they help us to understand that God has given us as the congregation everything we need in order to care for creation, his world. The Lord is indeed our Shepherd, we do not want. We have received what we need to know, to love and to serve him in his world.

How does he take care of his 'chosen'? He is with them, in and through his Spirit. He (and nobody else) is the comfort of the congregation. However many people he might employ to care for his own, he is the sole reason for our being and our becoming (cf. Gots 1988). In theology as such and from history we learn how he is present and how he takes care of his own. The ways in which he takes care of his own has taken on the name diakonia. He came to serve (Mk 10:45) and is serving his 'intermediary pastor', the congregation. In history this diakonia of the Son of Man has taken on different forms/modes (cf. Collins 1990).

\section{Ministry My understanding of ministry}

My approach is this article is ultimately that for any congregational analysis to have theological integrity, it will have to measure the congregation's faithfulness in ministry. It is therefore important to share something of my understanding of this critical concept in the building up of missional churches.

My understanding of the church/congregation goes back to my understanding of creation and the two stories of Genesis 1 and 2. The stories are probably not in the Bible to argue a case for the fact that God created this world. This was and is a confession of the faith of God's people who believed anyway and all the time that 'their help comes from the Lord who made heaven and earth' (cf. Ps 124). The purpose of the story is, in a sense, to let us know how God responded to a world and people who have made themselves gods in the image of man. He could not let go of what he has made and will always seek to find the lost and the hidden (cf. Gn 3:8). Kessler and Deurloo (2004:ix) put it this way: 'Genesis is a work of proclamation. Its narrative intends to convey the beginnings of God's acts on behalf of his people'. He does want the found ones to know that his plan and intention was different: He made man (humans) in his image and as his representative on planet earth. Who are they? They are the people who know, love and serve him, therefore being able to represent him. If we accept that Genesis 1 to 3 may be a later document than indicated by its place in our Bible ( $c f$. Kessler \& Deurloo 2004; Waltke and Fredricks 2001), we have to take the relational history of God into account when reading this commitment to creation and to us humans. He has established and restored what we have broken and failed in. Kessler and Deurloo write that

when we properly understand the name of the first biblical book, we can look beyond "the beginning" to the future. The important question is not how everything started, but rather what is its purpose.

(Kessler \& Deurloo 2004:3)

Brueggemann (2006:8-9) helps us a lot to look at 'us' in this way. With reference to Buber and Rosenzweig he speaks of creationcovenant-consummation as an ordered account of faith, of the large way in which faith sees the life of the world. He admits that this 'plot line' is too simple, but it helps to 'link the detail of our life to the presiding God, intimately connected to but not domesticated by the truth of our daily existence':

- Creation is the claim of the text that the life of the world is bounded by the self-giving generosity of God.

- Consummation is the claim of the text that the life of the world is bounded by God's utterly reliable fidelity.

- Covenant is the claim of the text that the current life of the world is intimately and determinedly held in relation to God's governance' (cf. Waltke and Fredricks 2001:43-45) who refer to this as the theme of Genesis and the Bible - 'The Kingdom of God').

Brueggemann (2001:59) later refers to 'this remarkable sense of origination in gift' when he describes Israel's life, and how it is expressed in the ancestral and exodus traditions. In a beautiful essay on evangelism and discipleship he, along the same lines, plays with the call and send nature of the church.

In Christ we are all a group of new people who begin to understand why we are here and why we are so important that even his son died to make us live again. This is not the place to argue the whole of our understanding of our reconciliation with God, one another and creation itself. The point in question and in relation to the research problem and hypothesis is that the church as we know it now, after Pentecost, is but God's new creation, restored and continuously being restored to its original purpose.

The church, then, is a creation of the Triune God. This is not to say that he is not in direct relationship with his 'world' itself. He is, but we confess that the church is no casual reality; it originates 
in the will of the Triune God. The church is part of this reality because through it God wants to express his rule over and in the lives of men. While the world denies, rejects and opposes this Lord and his dominion, the church confesses, accepts and serves him as the Only One. It is true that the church is 'temporary' and will at the completion of all things stop functioning as such, but it is equally true that in the interim the church, and every local congregation within it, is important because God regards it as important. Until the end comes, it pleases him to display his Kingdom by means of his Church. He does this by demonstrating what happens when he rules, and when people, as his possession, gladly confess, honour and serve him as King. Every congregation should plainly exhibit the Kingdom of God in the way it exists and functions. The congregation is not a secret exhibition to be thrown open on the last day; in the context of a world estranged from God it is already a public showcase: This is what God's rule is like. To expand the image: The congregation is a display window next to a pavement filled with secularised people who have turned their backs on God (and on his display window). In this sense the church is the bearer of the coming of the Kingdom in this world. The church is God's subject through whom he comes to the world - not that he cannot come to the world in other ways, but because this way has been revealed to us as his will. God still comes to the world, and a congregation is at its best when it serves and promotes the coming of God. Whoever wants to make the congregation the purpose of God's coming does not build a congregation, but merely a community or club of like-minded people. The members of a church who understand their Trinitarian origins, who align themselves to Christ as their Head, who take their Spirit-filled way of life seriously, find fulfilment in serving God because they think, believe and confess the same things about God and his kingdom (Nel 2005a:13-14)

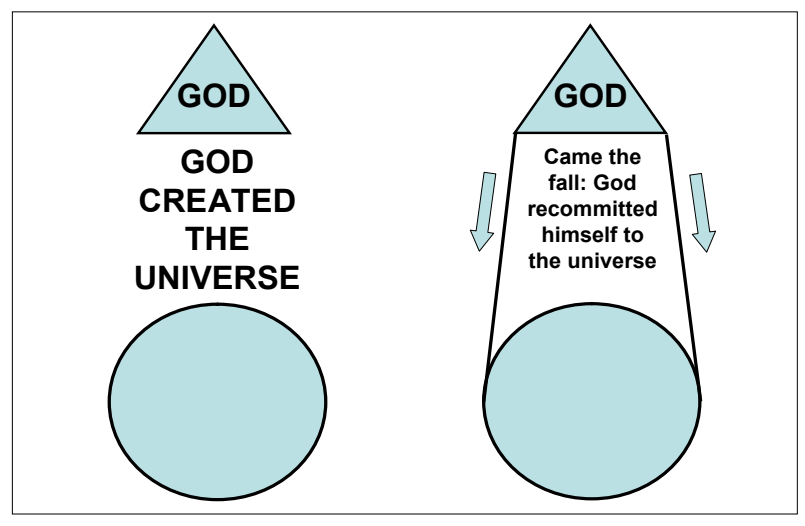

FIGURE 1

God's commitment to creation

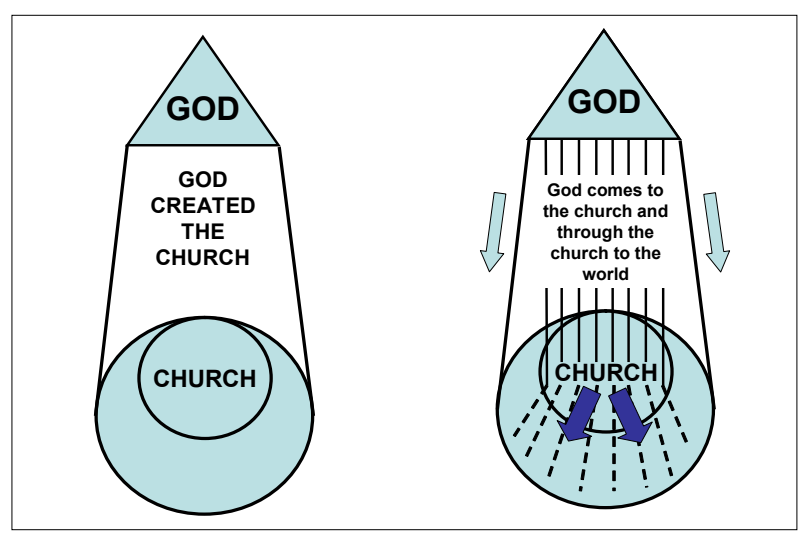

FIGURE 2

God's coming to church and world

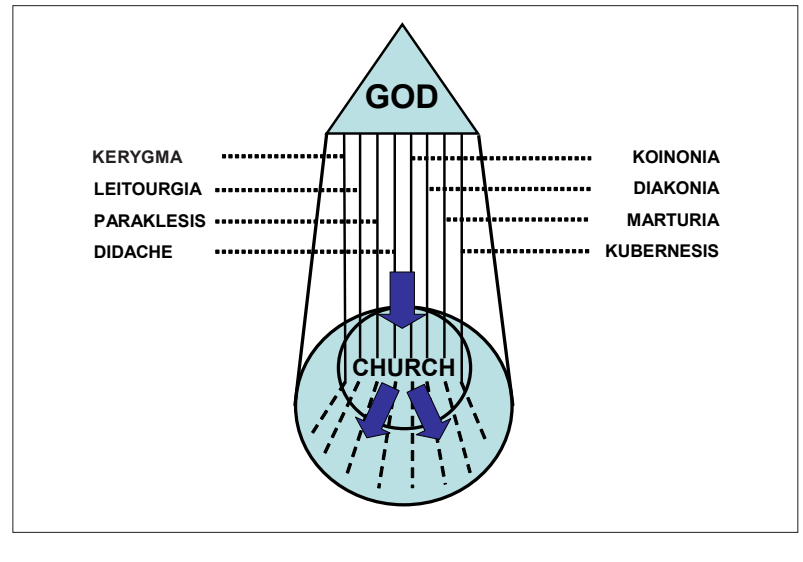

FIGURE 3
The modes of God's coming to church and world

Figures 1, 2 and 3 portray my understanding of the place and role of the church and every congregation (in context) as part of God's intention for the world.

\section{Pastoral role-fulfilment as intermediary}

Picking up on my theological mentor's (Firet) understanding of the subject field and broadening it in my own way, I understand ministry as God's coming to his people and his coming through them to his world. Ministries do not make God present. God comes through ministry to his people and the world. Firet (1986:13-15) uses the concept pastoral role-fulfilment for the role a pastor plays in God's coming. There are, however, references to the lay person viewed as subject 'with a unique calling and responsibility' (Firet 1986:13, citing Kraemer 1958:72). I believe it is fair and just to claim pastoral role-fulfilment not just for the pastor (as so well-developed in Firet's dissertation), but also for the congregation as subject in God's coming to one another and to the world. This remains faithful to Firet's point of departure:

[P]astoral role-fulfilment mediates the coming of God in his word... At the heart of pastoral role-fulfilment is not the act of a human being, but the action of God who, by the way of the official ministry as intermediary, comes to people in his word.

(Firet 1986:14, 15, 20)

In the words of Hobbs,

[T]he missional church represents God in the encounter between God and human culture ... It is a visible manifestation of how the good news of Jesus Christ is present in human life and transforms human culture to reflect more faithfully God's intentions for creation.

(Hobbs 2004:159)

The name we give to his coming is ministries. The greatest challenge to our faithfulness is not to let the ministries become the great issues. Whatever we do and whatever we call what we do: it must serve his coming in his word (for a fuller explanation of this understanding, $c f$. Nel 2005a:24-92 and the two diagrams on page 30 and 111). Firet points to this too when he writes:

The reality of God's coming in his word is dynamic; dynamic moments do not exist by themselves. They are 'the power' of the modes without which the modes could not be.

(Firet 1986:40)

He later works this out in what he calls the hermeneutic and agogic moments (Firet 1986:91-134). Pastoral role-fulfilment is the [dynamic] field in which God and man are brought together in a relationship of tension in which the word occurs which brings people to understanding and change (Firet 1986:133).

Before we focus on a few of the ministries, one more issue has to be stated: No human being or, in my case study, the congregation as a corporate unit, is a mere instrument in God's hand. (For an explanation of the use of the word instrument [skeuos] in Ac 9:15, cf. Maurer 1971:364-365.) With Firet (1986:129), I reject this notion. 
The outpouring of the Holy Spirit and the bestowal of charismata do not reduce a human being to the level of an instrument by means of which God, as the only really acting Subject, can do his work. The Holy Spirit takes this man risen from the dust and makes him really what he is intended to be: almost divine, crowned with glory and honour (Ps 8:6) - and in that wonderful freedom he may serve God in his coming to people in accordance with the gift given to him.

It was Van Ruler (1969:181; 1973:12, 28-29, 36-37) who coined the phrase Theonome reciprocity to explain this dynamic as part of the grace of God in his recreation plan. What in Christology is called substitution, is called reciprocity in Pneumatology. The Holy Spirit restores a relationship through the Mediator and with our Creator where we begin to understand our role as coworkers with and of God. The significance of the work of the Spirit is that he puts us to work. Our total existence begins to bear the mark of the work of the Father, Son and Holy Spirit.

Firet (1986:14) acknowledges that 'there are a number of distinguishable forms of pastoral role-fulfilment' and admits that in his study he limits himself to preaching, catechesis and pastoral care. The issue at stake is the fact that the total ministry in whatever form and under whatever name is a way in which God is coming to his congregation and through them to his world. The whole ministry consists of all the communicative acts that serve the communication of the gospel. Traditionally this whole field of ministry is divided into seven separate styles or modes (cf. Firet 1986:82 for an explanation of the concept mode as 'to measure of' meaning first 'measure', then 'mode' or 'manner'.) I have added a number eight in my explanation of the ministry and because of the almost obvious and logical importance of the ministry of the kubernesis (Nel 2005a:111). Each of these modes is mainly there to serve the communication of the gospel. Each mode of ministry and all of them together are threedimensional. This means that each should always be service to the Triune God, service to one another and service to the world. The communicative involvement of God with the church and the world is the 'given' that compels the congregation to orientate itself towards this three-dimensional focus on service. The crucial question that every mode of ministry has to answer is: is it a communicative act that serves the gospel with regard to God the believers as a body and the world? It can be schematically illustrated as in Table 1.

Building up/developing missional congregations is about the integration and coordination of all these modes of ministry. And each separate mode, as well as all of them as an integrated whole, is about the three-dimensional service mentioned above: serving God, one another and the world. The balanced diet of every healthy congregation is a synthesis of all these modes of service. Congregations who are 'picky' and only regard some modes of ministry as being important, only 'eating' those modes they like, are not involved in building up the local church in the biblical sense. Just as in the case of picky children, picky congregations have never learnt proper dietary habits. The leaders are often mere children of their own culture; they only serve what the congregation, as part of a given nation and culture, likes to eat. When this happens for long enough, an undernourished congregation is formed - a congregation that may stubbornly refuse to adapt to a different diet. A proper analysis may help to diagnose whether a specific congregation, at a given moment in its existence, lacks one or two of the above-mentioned modes of ministry. Choosing to focus, after the analysis, on certain specific modes of ministry does not, however, mean that the other modes are not equally important (for more about this $c f$. Nel 2005a: Part 2). It cannot be stressed enough that building up the local church has to take the whole of the ministry seriously in the service of the communication of the gospel. In the long run the congregation will not be able to live with less than that. Trying to do so is to begin a process of fatal impoverishment in the congregation, and ultimately such a congregation will die, even though things may continue to appear much the same as usual (cf. Nel 2005a:30-31).

\section{The ministries}

Subject fields have developed on each one of the ministries. The bulk of literature on each one is vast. One example of the vastness of the field of pastoral care is the Dykstra (2005) publication, in which he and his co-authors describe at least 19 'images' of pastoral care ( $c f$. also De Vries 2003:45-60) for a discussion on 'pastoraat als storing'). To make a case for a ministerial approach to congregational analysis, a brief description of each of the eight discerned ministries is necessary.

In this section the focus is on the interwoven and corporate nature of ministry. It has to be stressed again that our 'acts of service...are interwoven' (Nel 2005a:43), something Chesnut (2000:5) also notes when he writes:

In fact, one of the most significant points illustrated in the pages that follow is how everything the church does - from education to music, from spiritual life to social service and action - can be and should be simultaneously approached as an opportunity for evangelism.

(Chesnut 2000:5)

(meaning, in my words, the church in mission). This however does not take anything away from the uniqueness of the different ministries.

What needs to be remembered is that God Himself comes to his people through his Spirit, Word and Sacraments. His grace is the reason for our charismata, our preparedness to serve. Put differently, it means that he himself, Father, Son and Holy Spirit, refreshes and renews the congregation daily to be up to its task. Gibbs (1994:105) refers to it as the revitalisation and continuous transformation of the church. In Pauline understanding, it is about the work of the Spirit and ' $\mathrm{I}$ ' participate in the work of the Spirit and benefit from his work inasmuch as ' $\mathrm{I}$ ' am a part of the living body in which the Spirit dwells as the Giver of Life.

Ministry is both corporate (relational) and individual. Renewal of the personal life of the believer and the renewal of the congregation can and should not be separated. Far too often it is not related enough or related at all. Guder and others (Guder 1998:54) call the 'third disestablishment' in the process of moving away from Christendom 'the individualization of Society'. Culture is against a corporate understanding of ministry. Gots

TABLE 1

Building up the local church

THE CONGREGATION AND THE PROCESS OF BUILDING UP THE LOCAL CHURCH SERVES

the glorification of the Father, Son and Spirit

by the communication of the gospel

through the communicative acts that serve the gospel

$\begin{array}{lllll}\text { community } & \text { teaching } & \text { service } & \text { witness } & \text { leading } \\ \text { koinonia } & \text { didache } & \text { diakonia } & \text { marturia } & \text { kubernesis }\end{array}$

koinonia

didache

diakonia

marturia

kubernesis

often clustered into four 'ministries' 
(1988:290-299), who wrote a 336-page book on the renewing work of the Spirit, also focuses first on the 'Persönliche erneuerung des Lebens' and then on 'Erneuerung der Gemeinde', as long as the two are kept together, like inhaling and exhaling. The Holy Spirit is at work in the whole, the corpus Christi, the body of which ' $\mathrm{I}$ ' am a living member. This is too often underestimated and it may be the reason for rather spiritually poor congregations, even with spiritually arrogant individual members. Rolf Hille also makes this point as to the ecclesiology of the Deutschen Evangelischen Allianz and how they try to work with both:

Die Heilswirksamkeit des Glaubens stellt unmittelbar in die Christusherrschaft, von der die Existenz nicht nur des einzelnen Christen, sondern der gesamten Glaubensgemeinschaft bestimmt wird. Die Ekklesiologie is somit begründet in der Christologie als dem Wirkungsbereich des Geistes.

(Hille 1998:1-4)

Mann (1998:32) calls it the "movement from "I" to "We". The church as a different kind of community rediscovers the Biblical 'we' (cf. again Dick 2007:92: "We" is the word spoken most frequently in vital congregations').

Alston (1984:29) asks, 'When did the church become more than a collection of individuals? In other words when did the church become the church?' The answer: At the 'birthday of the church' in its New Testament gestalt.

Pentecost is the great rebirth of the church, when the people of God were reconstituted and renewed... [The early] Christian church experienced its rise not in isolated individual experience but its Christian koinonia or fellowship of those who shared in the profound and transforming experience of Jesus Christ ... Second, the Christian koinonia was understood as a new act of God, even though it was related to and consistent with his other acts in the history of Israel ... Third, the Christian koinonia was the context of inter-relatedness in which men and women grew into "real maturity" - that measure of development which is meant by "the fullness of Christ".

(Eph 4:13) (Alston 1984:30, 35)

I depart from this premise: The congregation is basically a relational unit. It was created and is being recreated (continuously) by God in a relationship of love. Reconciliation is a relational (covenant) concept. A missional church is 'a community that practices reconciliation' (Hobbs 2004:161). Ministry takes this seriously. It becomes almost a prerequisite for any ministry: to take this relational being of the congregation seriously. Easum (2001:66) names 'a solid community of faith' as the first 'unfreezing move' in a chapter he named 'Foundations of transformation and innovation'. This relational existence (eksistensie) is the reason for naming the ministries as I have done below.

\section{Relational service: Marturia and diakonia}

The reason for this ministry being discussed first is not to backtrack on the principle of interwovenness. It was already in 1983 that Callahan discovered that in congregations that are making a difference in societies, missional involvement is the number one reason. They bring help and hope in their part of God's world (Callahan 1983:1-10). Armstrong's story in the Oaklane Church, Philadelphia, dates back even further. It was this story filmed and published (Armstrong 1971) that led to his book (1979) on Service Evangelism. Since then many books have been published, developing what is now known as missional theology and thinking.

It is firstly because it is describing not only a ministry but the being of the congregation. It is a ministry test and an identity test at the same time. The role of the church in the coming of the Kingdom of God is at stake here. It is impossible to deal, in full, with the development of Bosch's (2002) argument for the 'intrinsically missionary' nature of Christianity and the church as such (summarised in pages 8-11, worked out in a book of 534 pages). His phrasing, as it relates to the Kingdom of God, is important at this point:
Christian mission gives expression to the dynamic relationship between God and the world ... Mission is God's "yes" to the world ... the world as the theatre of God's activity ... mission is "participating in God's existence in the world" (Schütz 1930:245, Bosch's translation) ... In our time, God's yes to the world reveals itself, to a large extent, in the church's missionary engagement in respect of the realities of injustice, oppression, poverty, discrimination, and violence.

(Bosch 2002: 8-11)

Cameron et al. study congregations because

increasingly, faith communities are perceived to have potential to provide resources in partnership with local government ... As places of belonging, and believing, they can offer much to enhance and strengthen the fabric of society in a multicultural world.

(Cameron et al. 2005:xiv)

Ammermann notes that

communities of faith define their mission in terms of external impact as well as in terms of their relationships with each other and with God ... congregations understand themselves to be under obligation to 'serve the world' in addition to serving their own members". She added that exactly this is "largely absent in the Other Religions.

(Ammerman 2005:115)

Chesnut's passionate plea is relevant here:

A fundamental spiritual challenge...does the Christian faith inspire us to become open, generous, and generative enough that we can think first not of satisfying ourselves and meeting our own needs but reaching out to populations we have not been reaching - to the unchurched, secular, but spiritually hungry people (many who are our own children and grandchildren, brought up in our mainline congregations); to people of other races and cultures; to different classes and younger generations in ways that will speak to them and meet their needs?

(Chesnut 2000:5)

According to Bosch (2002:10), evangelism is an 'essential dimension' of mission. Bearers of the good news of the Kingdom also invite others 'to become living members of Christ's earthly community and to begin a life of service to others in the power of the Holy Spirit' (Bosch 2002:10-11; also cf. the edition in honour of Peter Beyerhaus by Kniffa (1989) with the title Martyria). Bosch does not refer to Armstrong at all. It is only fair to, in this article, note that his description corresponds closely to Armstrong's (1979:53; 1996:2) definition of what service evangelism is. Armstrong explains clearly what it means to be a servant church in terms of the coming Kingdom (Armstrong 1979:47). The point is: Mission is a Kingdom-seeking venture into the world as the 'theatre of God's activity'. Joubert (2008:46) calls the Kingdom of God 'a new map of reality' for the church of the perfect storm.

An example of the sometimes subtle difference between a faithfulness (to these theological principles) and a growth approach in congregational analysis is relevant here. Here, because it is in this ministry that this distinction is the most obvious. Easum (2006) published a book on what he calls The complete ministry audit. The book comes with a CD-ROM and is indeed a complete, detailed audit, containing surveys and eventually the audit. Easum (2006:7), rightly so, to my mind, states that this is a diagnosis ( $c f$. my use of the concept in Nel 2005a:182) and not in the first place an evaluation. The audit then starts with the worship service and eventually is built around ' 19 growth principles' (Easum 2006:63-92). It is an excellent book and tool.

In this research of mine no one should get the impression that growth is not important in missional thinking. It is, but it is not motive (and I am not even suggesting that it is motive for Easum or for that matter for Schwarz 1996:20-21). I do however confess with Callahan (1990:19): 'The church is called to mission for the integrity of mission, not for the sake of church growth'. Or as Sjogren (2002:16) puts it: 'Bigger is not better, nor is it more effective. Church health is measured by competence, not by 
competition'. Or to concur with Dick:

Bigger says nothing about faithfulness, and active says nothing about effective. The value of our ministry is judged by the impact it makes on people's lives, not on how many people show up.

(Dick 2007:8)

Numbers do tell us something, but not everything (cf. Schaller 1998:58-88 in his discussion on 'what do the numbers tell us?'). Shawchuck and Rath refer to the principle of quality and write:

Large or small, the only churches to survive will be those that make Quality the standard in all that they do ... keeping at it until we exceed being the best, and set our sights on the highest goal of all - perfection.

(Shawchuck \& Rath 1994:12)

Dick picks up on this distinction again when he describes vital congregations:

The greatest difference between vital and dystrophic churches is the way they view growth. Dystrophic churches devote an enormous amount of energy to getting bigger; growth is a goal and an end in itself. In vital churches growth is a byproduct of healthy practices.. Vital congregations find that they have no trouble drawing and keeping new participants, though their numeric increases may not be as dramatic as most of their dystrophic counterparts.

(Dick 2007:90-91)

In building up missional congregations it is indeed about returning the ministry to the people and winning the unchurched and the 'dechurched' (Sjogren 2002:33) - people who have never been to church and those who are disillusioned with the church. Relational service is indeed a style by which congregations 'serve them back' (cf. Nel 2002:65-87). Sjogren (1993:22) calls this servant evangelism. In the emerging culture this may ask for a different kind of church. It may be not as radical as Easum has put it, but different indeed. In his opinion,

an army of recruits, plus involvement in ministry, plus minimal cognitive learning, multiplied by on-the-job training, minus professional clergy, equals a trained army of mobilized servants.

(Easum 2008:95)

A brief reference to the charismata is necessary at this point. For the sake of our servanthood we are gifted. God in Spirit, through Word and sacrament calls, commissions and equips the body for service, for ministry ( $c f .1$ Cor 12 ; Eph 4 ). This connection is necessary for the charismata to be and remain what it was given for. If not, it becomes a dividing principle as a doctrine. It is our confession of the congregation as a gifted community of servants that makes the congregation a carrier of hope and a co-worker in God's care for this world (cf. Baumgartner 1999:36-56; Ritt 1999:26-27; cf. also Grossmann 1998:163-168 for some theological guidelines for the 'Charismen im Gemeindebau').

In a proposed tool (to be published in 2010) for an analysis of this ministry of the relational missional involvement in communities, I will retain the rating guide that Callahan has developed after his consultation with some 1000 churches ( $c f$. Callahan 1990:17). I will however add some diagnoses of the congregations' understanding of their missional involvement as a Kingdom-seeking (including evangelism) ministry. Dick (2007:23) calls this 'impact awareness'. The book by Sider, Olson and Unruh (2002) about their research among 15 churches in the Philadelphia (Pennsylvania) area is a great example of even very small churches (of some 30 members) that touched and changed their communities for the betterment of the community. Sider et al. (2002:15-17) call it 'holistic ministry'. DeClaisse-Walford $(2005 ; 2006)$ in his $\mathrm{PhD}$ studies followed up on this research in the Atlanta area and came to similar conclusions as to why some churches are missionally holistic and others just have missional programmes. DeClaisse-Walford (2006:72-78) found that the top three characteristics of holistic congregations are the following:

- They hold to the centrality of Jesus in congregational life

- They believe that they are under the leadership of the Spirit

4. This book was written when it was already predicted that $60 \%$ of all congregations would be closed down by 2050 (Shawchuck \& Rath 1994:12).
- They have a clear understanding of the purpose of outreach ministry ( $c f$. also DeClaisse-Walford 2008:85-104).

This puts an analysis of the missional ministry in the realm of the spirituality of the congregation. Keifert's (2006) approach of discerning as body and Rendle and Mann's (2003) understanding of strategic planning as 'holy conversation' will be taken into account as well.

\section{Relational communication: kerygma and leitourgia}

Firet's (1986:15-50) understanding of the mode of the kerygma is to be seen against the backdrop of his explanation of the Word and its importance: 'The word of God is

- the form of the Lord's presence;

- the revelation of the Name;

- the revelation of the Truth; and

- the actualization of salvation'.

Firet (1986:44) acknowledges that several other words are used to carry the notion of announcing or proclaiming the gospel (cf. Louw \& Nida 1988, vol. 2:417-418) for the cluster. Firet (1986:4546) thinks that kerygma essentially 'proceeds from the conditions fulfilled in Jesus Christ ... [and] brings about the healing of life'. It is indeed the 'gospel of the Kingdom of God' (Lk 8:3). Acknowledging this in a sense summarises the reformational understanding of kerygma with preaching as the central form in which it comes to the church. Of preaching, kerygma is the central mode. Bosch (2002:9), in citing and translating Kramm, says: 'A theological foundation for mission, says Kramm, "is only possible if we continually refer back to the ground of our faith: God's self-communication in Jesus Christ"'. Hobbs (2004:16) writes that the team that worked with him discovered that in missional churches 'the story of God's salvation is faithfully repeated in a multitude of different ways'.

The understanding of ministry as serving the coming of God and the coming of the Kingdom is central in missional thinking ( $c f$. Keifert 2006:36-37). This is almost a faithfulness-check of any way the gospel is communicated: Is it the message of the King and his Kingdom? Armstrong's definition (and eventually of the Presbyterian Church [USA]) (Armstrong 1987:14, 15; 1996:2) of evangelism manages to formulate this central truth in being the church, serving the coming of God. Sjogren (1993; 2002:124-125), who is well known for his radical understanding of 'servant evangelism' (his 1993 term), also stresses this dimension. He does not link it directly to the kerygma, but in essence this is what is comes to. He cites Van Gelder (2000:75) to make his point:

The basic idea of the Kingdom of God is that God in Jesus powerfully entered human history with a reign that re-establish [sic] life on the basis of redemptive power ... it is about the dynamic presence of God's redemptive power confronting the forces of evil and restoring life to its fullness.

Van Gelder (2000:75)

Barrett et al. (2004:160) discern in their research that 'the missional church proclaims the gospel ... The story of God's salvation is faithfully repeated in a multitude of different ways'. More than one author points to the centrality of the gospel of Jesus, the Christ in vital churches. How difficult it is is stated beautifully by Campolo (1995:125) when he cites Kierkegaard:

[I]t is one thing for a man to so love people with God's love that he would give his life on a cross to save them. It is quite another thing, said Kierkegaard, for someone to expect to earn a good salary for once a week describing a man who gave his life on a cross.

(Campolo 1995:125)

Campolo immediately follows this up by saying that we need

Type A personalities with entrepreneurial risk-taking attributes in our pulpits. But more importantly, they must be balanced people who are constrained to serve because of their spirituality and love.

(Campolo 1995:125; cf. Nel [2001] for the impact of personality in preaching) 
It is little wonder that this ministry is so closely connected with and part of worship, the ministry of the leitourgia. 'Passionate worship' is very much part and parcel of what Schnase (2007:7, 33-57) calls 'fruitful congregations'. Schaller (2001:62-83) reports an interview with an African-American lady who was deeply involved in the development of a fully integrated congregation. She said that they had four priorities in getting this congregation up and running:

Our first was to identify our potential constituency. Our second was to build a program staff ..., third ... was to identity and enlist allies ..., fourth was to enlist a big nucleus of people before we held our first worship service.

(Schaller 2001:77-78)

As to this fourth, and in their ministry critical 'fourth', she says that they currently have three worship services to meet the needs of the congregation (rather than just buying into a subculture) and because 'upwardly mobile persons expect choices'. They planned to increase the four to seven after it was proven that people have choices of 144 TV shows. (According to Schaller (2001:77), seven of the 'ten that were most popular with blacks, were the seven least popular with whites'.) As important as leitourgia is, music is just as important. This is not the place to argue this point, but to state it (cf. Schaller 2001:136-141). Some say that is counts for up to $40 \%$ of the effectiveness of worship services in the perceptions of those who come (cf. Callahan 1994). Sider et al. (2002:16) found that the congregational life in holistic churches 'centers around passionate worship of the Triune God, celebrating salvation by grace through faith in Christ and relying on the power of God's Spirit for fruitful ministry'. Worship within missional congregations focuses on the Triune God. God is gathering 'us, nourishing us, equipping us, comforting us, calling and sending people in the movement and practices of Christian worship' (Keifert 2006:120). Satterlee, in his book on preaching in congregational transitions summarises in a beautiful way the importance of worship. He says:

Worship is central, most significantly, for theological reasons. Worship both reflects and shapes a community's faith. It expresses a congregation's view of God and enacts a congregation's relationship with God and each other ... Congregational worship should be integrated with the whole life of the congregation. It can serve as the "source and summit" from which all the practices of the Christian life flow.

Satterlee 2005:x)

It is no wonder that someone like Schnase $(2007: 7,11-57)$ in his research connects 'radical hospitality and passionate worship' as two of the five practices of fruitful congregations.

In the proposed tool for an analysis of this ministry of the leitourgia with preaching as a part of it, I will retain the rating guide that Callahan has developed after his consultation with some 1000 churches (cf. Callahan 1990:21). I will add some diagnoses about how worship (including preaching) serves the equipping of God's people for another week in real life; how it helps them seek the Kingdom of God in family and all other walks of life, whether as a body but more often as individuals, representing the body of Christ as missional gift to the world 'the theatre of God's activity' (Schütz 1930:245).

\section{Relational caring}

Paraklesis and koinonia belongs together like oxygen and life. Firet (1986:68-82), when discussing the paraklesis as the third mode of pastoral role-fulfilment, refers to the cluster of words used in Scripture for this ministry. Departing from what he calls the 'parakletic formula' (Firet 1986:71), the indicative of the 'because' ('by the mercies of God' [Rm 12:1]), he also refers to oikodomein as part of the cluster:

[I]t may be directed to the individual but it has the intent of drawing the individual out of her isolation and lead her to her place in the fellowship of the church.

(Firet 1986:81)
It starts with being in restored relationships with God in Christ. This is who we are 'in Christ'. Blewett (2008:101) plays with the words 'in' and 'around' in his contribution to the church in the perfect storm. In his article The turning of the tides, he says

you can be in or around, not in and around. It's like trying to be only a little bit pregnant. You can't do it; you are, or you aren't. You are either in [sic] relationship, or you are around a relationship.

(Blewett 2008:101)

One member of the family may be in this relationship for a shorter period than other members. But once you are, you are a caring, sharing member of a living organism. 'Caring and sharing' are the two concepts by which Callahan (1983:37) describes significant relationships. They

... are now baptized; their life is taken up into the story of the mercies of God, of the meekness and gentleness of Christ, of the love of the Spirit ... God comes to persons to rescue them out of the distress of their situation in order to bring them into life with the church in the enjoyment of salvation which is in Christ, comforted and courageous in the joy of new obedience. God leads them through this process to their own places and makes them fit to fulfil special tasks within the body of Christ.

(Firet 1986:71, 82)

In the paraklesis 'God comes ... [and it becomes] a life-function of the body of Christ which lives in the fellowship of the Spirit' (Firet 1986:76).

In describing the research by many well-known scholars ( $c f$. Nel 2009a) it was obvious that small groups are part and parcel of vital churches. Sometimes (as in the findings of Dick [2007]) the relational undertone is just there, never discussed specifically. At other times it was obviously discovered, such as in the research by Schwarz, where it is essential quality number 6 (Schwarz 1996:32-33). Another example is the Callahan (1983:11-23, 35-40) research, in which it has become characteristics 2 and 4, Callahan (1983:xii) calls the first six characteristics 'relational' characteristics. This is the reason why small groups are so often elevated as important in vital churches.

In the proposed tool for an analysis of this ministry of the pastoral care and koinonia, I will retain the rating guides that Callahan has developed after his consultation with some 1000 churches (cf. Callahan 1990:19, 23). Since Callahan's book was published, a lot has changed concerning pastoral visitation by pastors (and even shepherding elders in the reformed tradition). This will be taken into account and developed in consultation with South African pastors who are leading processes of reforming 'traditional' churches into missional 'outposts'.

\section{Relational didache}

One can say it any way around: Whoever takes the didache seriously takes discipleship seriously, or vice versa. 'In the didache God points out a new way of life' (Firet 1986:68). In essence this is a relational ministry. It is about being invited, initiated into a new way of life, being guided on this way and being helped to discern the things that really matter in this way of life (cf. Firet 1986:50-68 for a more detailed explanation). In some of the research cited in the article on empirical approaches to a congregational analysis (Nel 2009a), this ministry is not always called the didache. More often than not it is implied when researchers refer to 'spiritual disciplines' (McIntosh \& Reeves 2006:74-79), 'passionate spirituality' (Schwarz 1996:26-27), standards for membership (Dick 2007:10) and more (cf. a book that to my mind argues for the didache in a new way and with new terms, namely Finding our way again: The return of the ancient practices by McLaren [2008]).

A reminder: This is neither the place to argue the case for the didache as ministry nor to describe this ministry in any detail. The point in question is to state the importance of the ministry as a part of God's coming to his people and through his church to the 
world. This is in essence what Matthew 28:19 is about: disciples making disciples. Learners, people on the way, learning how to live life on this way (Way), inviting others to join 'us' on the way of learning how to live life while we follow 'the Way, the Life and The Truth' (Jn 14:6), Jesus Christ. Dick (2007:91), in his important findings from 717 congregations, states that 'vital congregations take discipleship and stewardship serious' [sic]. Add to this the centuries' long relationship between this ministry and youth ministry. For many centuries youth ministry was almost nothing but 'Christian Education' (cf. Nel 2005a:59, 77; 2005b:59-97). When one takes this into account, Campolo's (1995:133) remark is even more important: 'Of all the failures of mainline churches over the last three decades, none has been more pronounced than their failure in Youth Ministry'. Woolever and Bruce note as one of the universal strengths among congregations the fact that they

seek to educate worshipers about the faith and the behaviors expected of the faithful. Educational efforts aimed especially at the young may extend to starting schools where secular and religious education coincides.

(Woolever \& Bruce 2004:3)

Put differently, Walters postulates:

Catechetical programs because they are by design intended to make a noticeable difference in people's lives must concern themselves with effectiveness. Did the program accomplish what it set out to do?

(Walters 1984:5)

In the proposed tool for an analysis of this ministry of the didache I will develop a new rating guide for the guidance of youth and adults in a life of developing passionate spirituality and faithfulness in following Christ. Apart from using three specific sources (Dingemans 1986; Heitink 2007; Osmer 1992; 1996), I will also work with South African pastors who are leading processes of reforming 'traditional' churches into missional 'outposts'. I will seriously consider the findings of Barrett et al. (2004), that the missional church is a community where all members are involved in learning to become disciples of Jesus ... [where] the Bible is normative in this church's life ... [where] people within the community hold themselves accountable to one another in love (my understanding of discipl(e)-ine - MN) (Barrett et al. 2004:160-161).

\section{Relational leadership and administration: Kubernesis}

Almost all the researchers described in the article on empirical approaches to a congregational analysis ( $\mathrm{Nel} \mathrm{2009a)} \mathrm{touch} \mathrm{on}$ the importance of leadership. Campolo (1995:119-132) refers to leadership as possibly the critical issue in a mainline turnaround. He says that seminaries

... are not teaching pastors how to build great churches. We need ministers who have the well-honed skills of entrepreneurs. When looking at the growing congregations of America, they all have pastoral leaders who grasp the basic skills of programming, marketing, and institutional organizing ... it is competing for people's attention with all kinds of other institutions and activities, including other churches.

(Campolo 1995:129)

In a recent publication, Aleshire (2008:45) states: 'I believe that theological education for ministry is leadership education' (cf. also Hamman [2007:vii] for an in-depth discussion on what he calls our 'formation and transformation for pastoral ministry'). Avery (2002:7) states that 'at least in the United States pastoral leadership remains perhaps the key factor in the health of a congregation'. Currently I know of no other field of research in practical theology where so much is published as in the field of leadership ( $c f$. as a good resource book Gibbs 2005). The outcome of a very comprehensive research project of pastoral leadership is available in ten reports from the Duke Pulpit \& Pew Center for Excellence in Ministry (pulpitandpew@div.duke.edu). Several books have been published. With regard to this research
I refer the reader to the report on the findings relating to pastoral leadership and the shaping of congregations (Carroll 2006, with specific reference to pages 127-158).

Leadership is critical, but so is the broader understanding of this ministry of the kubernesis: the charge of taking a ship that you do not own, with a cargo you do not own to a destination determined by the owner of the cargo (who most probably only rented the ship for this purpose). This is, at least in part, the image of the concept Paul employs to describe this ministry (Luecke \& Southard 1986:50). The concept as used in the Greek world refers to 'being able to lead' or 'being able to get others to follow' (Louw \& Nida 1988:466, 548). Beyer (1965:1035-1037) writes that the duty to steer a ship (helmsman) was also figurative for a statesman. It could refer to 'the one who knows the times of the day and the year, the sky, the stars, currents of air ...' and therefore 'qualifies to direct the ship' (Beyer 1965:1035). In the three times it is used in the LXX it is closely related to wisdom and means 'clever direction' (Beyer 1965:1036). According to Beyer (1965:1036), it refers (in 1 Cor 12:28) to the gift of 'a true director of its (the body - MN) order and therefore of its life'. Luecke and Southard (1986:50) say that they think a modern-day thermostat is a good example of what the helmsman had to do: set a clear direction, have the ability to pick up when off track and thirdly have the ability to set actions in motion to get back on track. The role of the pastor in this ministry is challenging and one that asks for redefining. Horner (2008), who went through these kinds of redefined roles and challenges, wrote his book over a period of 10 years. The seven challenges pastors face are described in the book. His experience was the motivation to write a book on

how to develop and maintain a balanced spiritual life in the midst of challenging ministry situations. Learning to lead by leaning more on Christ forced me to depend on him to show me what he had in store for me.

(Horton 2003:10; cf. also Callahan's good book on new beginnings for pastors [1999] and Armstrong and Morledge [2005]).

One of the most serious challenges in building up missional churches is to find leaders (paid and volunteer) who understand the relative and the relevant nature of leadership, administration and management (the kubernesis). In this ministry, maybe even more so, one must understand the nature of ministry and the interwovenness of all ministries in service of the communication of the gospel of the Kingdom of God. If one pictures the congregation (and its ministries) as a train, faithfully serving its purpose, then the ministry of the kubernesis is the wheels. They take the hammering to make it happen. This ministry gets us there. Or in a worst case scenario, it acts as a brake, making it almost impossible to find direction and fulfil the mission of the congregation.

The last eight characteristics in the Callahan research (1983: xiii) concern this ministry. Are these components of the kubernesis important? Yes, they are, but in a different way than the relational characteristics. There is even a difference between leadership resources and, for instance, financial resources and the application of these resources. Leadership, in the Callahan analysis, at least, is still part of the relational characteristics. The main difference is that if the kubernesis is not in place (the wheels are not oiled), these components are the obvious causes of 'dissatisfaction'. The congregation is painfully aware of it. When they are working as a well-oiled machine, they unfortunately do not necessarily bring about 'satisfaction' (cf. Callahan 1983:xiv$\mathrm{xv})$, they only take away dissatisfaction.

In the proposed tool for an analysis of this ministry of the kubernesis I will continue to use most of the rating guides as proposed by Callahan (1990:24, 25, 27-34). I will also consider questions from the audit as proposed by Easum (2006:63-92) and references to important traits in leadership by Schwarz (1996:2223) and Schwarz and Schalk (1998:47-54). This will be taken 
into account and developed in consultation with South African pastors who are leading processes of reforming 'traditional' churches into missional 'outposts'.

\section{VARIABLES IN CONGREGATIONAL ANALYSIS}

For the sake of being somewhat complete I need to briefly mention a few variables that come into play, even before a ministry analysis takes place, as foreseen and proposed above.

\section{Size}

Size does make a difference. There are different ways to refer to different size churches. Rothauge (1983:5 and Mann [1998:3], picking up on this), focussing on 'new members ministry' came up with the following distinction (according to worship attendance):

- 50 members active and attending worship ... FAMILY CHURCH;

- 50-150 active members ... PASTORAL CHURCH;

- 150-350 active members ... PROGRAM CHURCH;

- 350-500 and over active members ... CORPORATION CHURCH.

Beth et al. (2001) used the same distinctions, but with a focus on transitions between sizes - either growing larger or declining to smaller. Another approach is the one used by Callahan (1990:8, 9) and by McIntosh (1999:22), where average worship attendance is the main variable. They came up with three sizes:

- Small church: 15-200 regularly in worship: $80 \%$ of all churches

- Medium church: 201-400 regularly in worship: 10\% of churches

- Large church: $401+$ regularly in worship: $10 \%$ of churches

Size impacts on ministry and is therefore a critical variable in congregational analysis.

\section{Type of church}

Too often only two types of churches were discerned: growing or declining (dying). I have already referred to the remarks by Dick that such a distinction may be 'misdirected, or even wrong' (Dick 2007:8). However important this distinction is, it is not the only one. Where growth becomes the measure of success, an end in itself, it is wrong. In the proposed tool for a congregational analysis within the frame of this research I will employ the four types of churches as distinguished by Dick (2007:10-14): vital, dystrophic, retrogressive and decaying (cf. also Nel 2009a).

\section{Context}

Contexts require separate analyses to be helpful (cf. Nel 1994:148154; 2005a:177-189; Hendriks 2004:69-103). It is better when it precedes a congregational analysis or diagnosis. The important thing in a tool for an analysis is for a local church to 'classify' its context with regard to demographics and geography. Both give entrance into what may be called the cultural context. With regard to demographics, the consulting services offered by the Unit for Religious Demographic Research at Stellenbosch University can help local churches determine the demographic data of their area. With regard to geography, a basic discernment is in place using, as Hendriks (2004:43) calls it, 'social location' as variable:

- Small rural congregations (one pastor)

- Rural congregations (with two to four pastors)

- Larger town congregations (where more than four ministers serve)

- Apartment and extra-ordinary congregations (downtown or inner-city congregations with high-rise buildings...student congregations, congregations for deaf and blind people, etc.)

- Suburban congregations (cf. Bisschoff \& Schoeman 2000:4)

\section{Theological alignment}

I am seriously considering (and will consult the working group referred to) to use the seven streams of religious traditions as discerned by Ammermann (2005:4) in American congregations (based on the number of congregations, not adherents):

- Conservative Protestant 52\%

- Mainline Protestant 26\%

- African American Protestant 8\%

- Catholic and Orthodox 6\%

- Sectarian groups 3\%

- Jews $1 \%$

- Other religions $4 \%$

This can serve both as a discernment of congregational theological alignment as well as an analysis of the religious society of the local church ( $c f$. also Hendriks [2004] for his description of the role of theology in the analysis).

\section{EXAMPLES OF QUESTIONNAIRES TO BE CONSULTED}

For the sake of completeness, reference (at the end of the reference list) is given to the different questionnaires that will be considered and referred to when cited.

\section{CONCLUSION}

\section{A ministry analysis}

The approach argued above is based on my understanding of

- the missional identity of the congregation;

- the congregation as intermediator in the coming of God to His world; and

- the church's main reason for existence, namely enjoying the King while serving the coming of his Kingdom.

I suggest an approach that does not so much focus on what churches do to grow. The focus is an attempt to get congregations to reflect theologically on who they are and where they are going; and then to ask the integrity and faithfulness question: Are we serving God's coming to us and through us to our context, our world, his world within our reach? I call this a more theological approach to congregational analysis, a ministry or even ministerial analysis.

\section{Analysing faithfulness to the gospel of the Kingdom}

What we have received we have received to give. This is the rhythm of the Kingdom: If you do not give it away, you lose it (cf. Eickhoff 1992:13-17). It corresponds to the well-known rule in rugby: use it or lose it. These are the marks of a faithful intermediary pastor/congregation. Getz (1975:12) calls this a mature church. Seeking the Kingdom is the main business of the church and of every ministry. It is a non-negotiable. If we do not seek the Kingdom of God, we have sold our birthright.

\section{Faithfulness and the marks of the church}

Referring to the names we are called, the metaphors we are named with are not intended to ignore the so-called marks of a true church. Especially within the Reformed tradition, the three marks of a true church are well known and confessed to be relevant and valid: true preaching of the Word, proper observance of the sacraments and faithful exercise of church discipline. It is also true that Calvin (Institutes IV.2.1) defined only the first two marks in the Institutes, but included discipline in the proper observance of the sacraments. The ministry of 
the Word and sacraments is, he says, 'a perpetual mark and characteristic of the Church'.

The contention in this article is that these 'markers' as well as the 'attributes' of the church as expressed in the Nicene Creed apply to whatever mode of ministry the congregation is involved in. It is the ultimate test for the plan, meaning the congregation. It is the backdrop and the ultimate 'rule' against which we are to be the 'intermediary pastor', serving God's presence among us and his coming to the world. This backdrop and ultimate rule has to be taken seriously when analysing, for example, the ministries. The golden thread running through any analysis is exactly these attributes and marks of the church. Ultimately this is what distinguishes the congregation from a secular business. Even businesses have commonalities that distinguish a company to be a business. Congregations, worldwide, have similarities. This is what makes a congregation a recognisable expression of the one body of Christ: We believe in one, holy, catholic, apostolic church that proclaims the Word, observes the sacraments and lives faithfully as disciples of the Christ.

\section{Expressing God's love for the world}

In essence, the congregation is an expression of God's love for the world. Congregations are indeed his chosen vehicles to the world, in any given context. They are his gift to their context. They are God's search parties for the lost and the broken, the victims of the accidents in life. To be and to stay roadworthy vehicles, gifts whose shelf life date is still valid, search parties who are well prepared for every possible search, they need one another. Presbyteries, synods, dioceses, districts (or whatever the family meetings are called) are but confessional consciences and, in the meaning of the metaphor of the vehicle, repair shops - helping one another stay roadworthy and faithful vehicles of God's grace in Christ and through the Spirit.

\section{Reforming congregations to missional outposts}

How difficult the process of a new dawning is is well stated by Barbara Hixon when she writes about her denomination that for a thousand years has been 'conservationists' (her italics),

but came along Vatican II, a veritable earthquake, cracking the Roman rock to expose its component pebbles: the people of God ... We are as yet uncomfortable with it. Living Rock moves. That means changing, reshaping, leveling mountains, and filling valleys. It means making way for the Lord. The switch from conservation to transformation is difficult. Difficult but rewarding. On this reformational road congregations are faced with the research question of this and the previous article: How can we do a congregational analysis in a practical and theologically faithful and scientific way?

(Barbara Hixon 1997:63)

We can and we should when taking seriously

- the theological identity of the congregation. It impacts and in more than one way determines when and how we analyse

- the theological and empirical identity of congregations that informs the need for and the content of the analysis (approach, methods and content)

- the theological and empirical identity that determines the kind of process and the outcomes of the analysis (strategies).

\section{REFERENCES}

Aleshire, D.O., 2008, Earthen vessels: Hopeful reflections on the work and future of theological schools, Eerdmans, Grand Rapids.

Alston, W.M. Jr., 1984, The church: Guides to the Reformed tradition, John Knox, Atlanta.

Ammermann, N.T., 2005, Pillars of faith: American congregations and their partners, University of California Press, Berkeley.

Ammermann, N.T. \& Farnsley II, A.E., 1997, Congregation and community, Rutgers University, New Brunswick.
Armstrong, R.S., 1971, The Oaklane story: The renewal of a city church which started ringing doorbells, United Presbyterian Church in the USA, New York.

Armstrong, R.S., 1979, Service evangelism, Westminster, Philadelphia.

Armstrong, R.S., 1987, Faithful witnesses: Participant's book, Geneva, Philadelphia.

Armstrong, R.S., 1996, Faithful witnesses mini course. Participant's workbook: An evangelism training course for Presbyterians, PCUSA, Louisville.

Armstrong, R.S. \& Morledge, K.W, 2005, Help! I'm a pastor: A guide to parish ministry, Westminster John Knox, Louisville.

Avery, W.O., 2002, Revitalizing congregations: Refocusing and healing through transitions, Alban, Bethesda.

Barna, G., 2002, The state of the church, Issachar Resources, Ventura.

Barrett, L.Y. (ed.), 2004, Treasure in clay jars: Patterns in missional faithfulness, Eerdmans, Grand Rapids.

Barth,K., 1962, Church dogmatics, IV/1: The doctrine of reconciliation, transl. G.W. Bromiley, T \& T Clark, Edinburgh.

Bauman, Z., 1995, Life in fragments: Essays in postmodern morality, Blackwell, Oxford.

Baumgartner, K., 1999, 'Diakonie im Geist', in K. Baumgartner (ed.), Gemeinde Gestalten, pp. 35-67, Friedrich Pustet, Regensburg.

Baumgartner, K., (Hrsg.), 1999, Gemeinde Gestalten, Friedrich Pustet, Regensburg.

Beth, A.G. (ed.), 2001, Size transitions in congregations, Alban, Bethesda.

Beyer, H.W., 1965, 'Kubernein', in G. Kittel (ed.), Theological Dictionary of the New Testament IV, pp. 1035-1037, transl. G.W. Bromiley, Eerdmans, Grand Rapids.

Bisschoff, J. \& Schoeman, K., 2000, Kerkspieël, NG Kerk, Pretoria.

Blewett, M., 2008, 'The tides are turning', in L. Sweet (ed.), The church of the perfect storm, pp. 99-108, Abingdon, Nashville.

Bosch, D.J., 2002, Transforming mission: Paradigm shifts in theology of mission, 7th edn., Orbis, Maryknoll.

Brouwer, R., De Groot, K., De Roest, H., Sengers, E. \& Stoppels, S., 2007, Levend lichaam: Dynamiek van Christelijke geloofsgemeenschappen in Nederland, Kok, Kampen.

Brueggemann, W., 2006, in Miller, P.D. (ed.), The word that redescribes the world: The Bible and discipleship, Fortress Press, Minneapolis.

Bullard, G.W. Jr., 2006, Pursuing the full Kingdom potential of your congregation, Lake Hickory Resources, St Louis.

Callahan, K.L., 1983, Twelve keys to an effective church: Strategic planning for mission, Harper \& Row, San Francisco.

Callahan, K.L., 1987, Twelve keys to an effective church: The planning workbook, Harper \& Row, San Francisco.

Callahan, K.L., 1990, Effective church leadership: Building on the twelve keys, Harper \& Row, San Francisco.

Callahan, K.L., 1994, Dynamic worship: Mission, grace, praise, and power - A manual for strengthening the worship life of twelve keys congregations, Harper \& Row, San Francisco.

Callahan, K.L., 1999, A new beginning for pastors and congregations: Building an excellent match upon your shared strengths, JosseyBass, San Francisco.

Calvin, J., 1960, Institutes of the Christian religion, ET, Philadelphia.

Cameron, H., Richter, P., Davies, D. \& Ward, F. (eds.), 2005, Studying local churches: A handbook, SCM, London.

Campolo, T., 1995, Can mainline denominations make a comeback?, Judson, Valley Forge.

Carroll, J.W., 2000, Mainline to the future: Congregations for the $21^{\text {st }}$ century, Westminster John Knox, Louisville.

Carroll, J.W., 2006, God's potter: Pastoral leadership and the shaping of congregations, Eerdmans, Grand Rapids.

Carroll, J.W., Dudley, C.S. \& Mckinney, W. (eds.), 1986, Handbook for congregational studies, Abingdon, Nashville.

Chesnut, R.A., 2000, Transforming the mainline church: Lessons in change from Pittsburgh's Cathedral of Hope, Geneva, Louisville. 
Clowney, E.P., 1995, The church: Contours of Christian theology, InterVarsity Press, Downers Grove.

Collins, J.N., 1990, Diakonia: Re-interpreting the ancient resources, Oxford University Press, New York.

DeClaisse-Walford, S.G., 2005, 'Led by the Spirit? Discovering the ethos of congregations that reach out', PhD dissertation, University of Pretoria, South Africa.

DeClaisse-Walford, S.G., 2006, 'How should the church then live? "Holistic" congregations as models for church life', Practical Theology in South Africa 21(1), 61-85.

DeClaisse-Walford, S.G., 2008, Mission as holistic ministry: Developing a congregational ethos of community engagement, Smith \& Helwys, Macon.

Dekker, G., 2000, Zodat de wereld verandert: Over de toekomst van de kerk, Ten Have, Baarn.

De Reuver, R., 2004, Eén kerk in meervoud: Een theologisch onderzoek naar de ecclesiologische waarde van pluraliteit, Boekencentrum, Zoetermeer.

De Vries, R., 2003, 'Pastoraat als storing', in G. Immink H. de Roest (eds.), Praktische theologie in meervoud, pp. 45-60, Meinema, Zoetermeer.

Dick, D.R., 2007, Vital signs: A pathway to congregational wholeness, Discipleship Resources, Nashville.

Dingemans, G.D.J., 1986, In de leerschool van het geloof: Mathetiek en vakdidactiek voor catechese en kerkelijk vormingswerk, Kok, Kampen.

Dudley, C.S. \& Ammermann, N.T., 2002, Congregations in transition: A guide for analyzing, assessing, and adapting in changing communities, Jossey-Bass, San Francisco.

Dykstra, R.C. (ed.), 2005, Images of pastoral care: Classic readings, Chalice, St Louis.

Easum, W.M., 2001, Unfreezing moves: Following Jesus into the mission field, Abingdon, Nashville.

Easum, W.M., 2006, The complete ministry audit, rev. edn., Abingdon, Nashville.

Easum, W.M., 2007, A second resurrection: Leading your congregation to new life, Abingdon, Nashville.

Easum, W.M., 2008, 'Mid-storm equations for the emerging church', in L. Sweet (ed.), The church of the perfect storm, pp. 89-98, Abingdon, Nashville.

Ebeling, R., 1998, 'Freikirche - Volkskirche - Bekennende Kirche', in H. Stadelmann (ed.), Bausteine zur Erneuerung der Kirkche: Gemeindeaufbau auf der Basis einer biblisch erneuerten Ekklesiolgie, pp. 41-56, Brunnen, Giessen.

Eickhoff, K., 1992, Gemeinde entwickeln für die Volkskirche der Zukunft: Anregungen zur Praxis, Vandenhoeck \& Ruprecht, Göttingen.

Firet, J., 1986, Dynamics in pasturing, transl. J. Vriend, Eerdmans, Grand Rapids.

Fuchs, O., 2001, 'Identität der Gemeinde: Praktisch-theologisch Impulse zu ihren Grundvollzügen', in W. Krieger \& B. Sieberer (eds.), Gemeinde der Zukunft-Zukunft der Gemeinden, pp. 43-85, Echter, Würzburg.

Getz, G.A., 1975, The measure of a church, Regal, Glendale.

Getz, G.A., 1984, Sharpening the focus of the church, Victor, Wheaton.

Gibbs, E., 1993, Winning them back, Eerdmans, Grand Rapids.

Gibbs, E., 1994, In name only, BridgePoint, Wheaton.

Gibbs, E., 2005, LeadershipNext: Changing leaders in a changing culture, InterVarsity Press, Downers Grove.

Gots, A., 1988, Du machts uns neu durch Deinen Geist: Grundkurs der Glaubenserneuerung Styria, Verlag Styria, Graz.

Grossmann, S., 1998, 'Die Bedeutung der Charismen im Gemeindebau: Leitlinien für eine theologisch verantwortete Umsetzung der neutestamentlichen Charismenlehre', in H. Stadelmann (ed.), Bausteine zur Erneuerung der Kirkche: Gemeindeaufbau auf der Basis einer biblisch erneuerten Ekklesiolgie, pp. 163-168, Brunnen, Giessen.

Guder, D.L. (ed.), 1998, Missional church: A vision for the sending of the church in North America, Eerdmans, Grand Rapids.

Hamman, J.J., 2007, Becoming a pastor: Forming self and soul for ministry, Pilgrim, Cleveland.
Heelas, P., Lash, S. \& Morris, P. (eds.), 1996, De-traditionalization: Critical reflections on authority and identity at a time of uncertainty, Blackwell, Cambridge MA.

Heitink, G., 2007, Een kerk met karakter: Tijd voor heroriëntatie, Kok, Kampen.

Hendriks, H.J., 2004, Studying congregations in Africa, Lux Verbi $\mathrm{BM}$, Wellington.

Hervieu-Léger, D., 2000, Religion as a chain of memory, transl, S. Lee, Rutgers University Press, New Brunswick.

Heyns, J.A., 1977, Die kerk, NGKB, Pretoria.

Hille, R., 1998, 'Perspektiven evengelikaler Ekklesiologie: Dargestellt an der Glaubensbasis der Deutschen Evangelischen Allianz', in H. Stadelmann (ed.), Baustene zur Erneuerung der Kirche: Gemeindeaufbau auf der Basis einer biblisch erneuerten Ekklesiologie, pp. 1-8, Brunnen, Giessen.

Hixon, B., 1997, RCIA spirituality: Formation for the Catechumenate Team, rev. edn., Resource Inc., San Jose.

Hobbs, W.C., 2004, 'Method: Indicators of a missional church', in L.Y. Barrett (ed.), Treasure in clay jars: Patterns in missional faithfulness, pp. 154-172, Eerdmans, Grand Rapids.

Hoekendijk,J.C.,1948, Kerken Volkin de Duitse Zendingswetenschap. Bydragen tot de Zendingswetenschap Part 1, Kampert \& Helm, Amsterdam.

Hoekendijk, J.C., 1952, 'The church in missionary thinking', The International Review of Missions XLI, 324-336.

Hoekendijk, J.C., 1966, The church inside out, Westminster, Philadelphia.

Holifield, E.B., 1994, 'Toward a history of American congregations', in J.P. Wind \& J.W. Lewis (eds.), American congregations vol. 2, New perspectives in the study of congregations, pp. 23-53, University of Chicago Press, Chicago.

Hopewell, J. (ed.), 1984, The whole church catalog: Where to get tools for congregational study and intervention, Alban, Washington, D.C.

Horner, D., 2008, A practical guide for life and ministry: Overcoming 7 challenges pastors face, Baker, Grand Rapids.

Horton, M., 2003, 'Better homes \& gardens', in L. Sweet (ed.), The church in emerging culture: Five perspectives, pp. 105-138, Zondervan, Grand Rapids.

Howe, R., 1959, The creative years, Seabury, New York.

Immink, G. \& De Roest, H. (eds.), 2003, Praktische theologie in meervoud, Meinema, Zoetermeer.

Jonkers, J.B.G. \& Bruinsma-de Beer, J. (eds.), 2000, Gemeente Gewogen. Een introduksie op het theologische gesprek over de lokale kerklijke gemeente, Kok, Kampen.

Joubert, S.J., 2008, 'In sync with Jesus and the first perfect stormers', in L. Sweet (ed.), The church of the perfect storm, pp. 42-51, Abingdon, Nashville.

Keifert, P., 2006, We are here now: A new missional era - A missional journey of spiritual discovery, Allelon, Eagle.

Kessler, M. \& Deurloo, K., 2004, A commentary on Genesis: The book of beginnings, Paulist, New York.

Kniffa, J. (ed.), 1989, Martyria. Festschrift zum 60. Geburtstag von Peter Beyerhaus am 1.2.1989, Brockhaus, Zürich.

Kraemer, H., 1958, Theology of the laity, Westminster, Philadelphia.

Kramm, T., 1979, Analyse und Bewährung theologischer Modelle zur Begründung der Mission, Missio Aktuell Verlag, Aachen.

Krieger, W. \& Sieberer, B. (eds.), Gemeinde der Zukunft - Zukunft der Gemeinden, Echter, Würzburg.

Louw, J.P. \& Nida, E.A. (eds.), 1988, Greek-English lexicon of the New Testament: Based on semantic domains, United Bible Societies, New York.

Luecke, D.S. \& Southard, S., 1986, Pastoral administration: Integrating ministry and management in the church, Word, Waco.

MacIntyre, A.C., 1984, After virtue: A study in moral theory, University of Notre Dame Press, Notre Dame.

Malphurs, A., 1993, Pouring new wine into old wineskins: How to change a church without destroying it, Baker Books, Grand Rapids.

Mann, A., 1998, The in-between church: Navigating size transitions in congregations, Alban, Bethesda. 
Mann, A., 1999, Can our church live? Redeveloping congregations in decline, Alban, Bethesda.

Maurer, C., 1971, 'Skeuos', in G. Kittel (ed.), Theological Dictionary of the New Testament, transl. G.W. Bromiley, pp. 358-367, Eerdmans, Grand Rapids.

McIntosh, G.L., 1999, One size doesn't fit all: Bringing out the best in any size church, Fleming H. Revell, Grand Rapids.

McIntosh, G.L. \& Reeves, R.D., 2006, Thriving churches in the twenty-first century: 10 life-giving systems for vibrant ministry, Kregel, Grand Rapids.

McLaren, B.D., 1998, Reinventing your church, Zondervan, Grand Rapids.

McLaren, B.D., 2000, The church on the other side, Zondervan, Grand Rapids.

McLaren, B.D., 2004, A generous or+hodoxy, Zondervan Emergent Youth Specialties, Grand Rapids.

McLaren, B., 2008, Finding our way again: the return of the ancient practices, Thomas Nelson, Nashville.

McLaren, B.D. \& Campolo, T., 2003, Adventures in missing the point: How the culture-controlled church neutered the gospel, Zondervan Emergent Youth Specialties, Grand Rapids.

Minear, P.S., 2004, Images of the church in the New Testament, John Knox, Louisville.

Nel, M., 1994, Gemeentebou, Orion, Halfway House.

Nel, M., 2001, Ek is die verskil, CLF, Bloemfontein.

Nel, M., 2002, "'Serving them back": Youth evangelism in a secular and postmodern world', Journal of Youth and Theology 1(1), 65-87.

Nel, M., 2005a, Who are we? Understanding and finding identity in the local church, Kitskopie, Pretoria.

Nel, M., 2005b, Youth ministry. An inclusive congregational approach, Zondervan, Pretoria.

Nel, M., 2006, Stories van hoop, CUM, Vereeniging.

Nel, M., 2009a, 'Congregational analysis: Empirical approaches', HTS Teologiese Studies/Theological Studies, 65(1), Art. 187, 13 pages. DOI: 10.4102/v65i1.187

Nel, M., (2009b forthcoming), 'Inviting and initiating youth into a life of discipleship', to appear in Verbum et Ecclesia.

Neuner, P. (Bearbeitet), 1994, Ekklesiologie I. Texte zur Theologie Dogmatik, Styria, Graz.

Neuner, P. (Bearbeitet), 1995, Ekklesiologie II. Texte zur Theologie Dogmatik, Styria, Graz.

Nyamiti, C., 2007, Studies in African Christian Theology, vol. 3, Some contemporary models of African ecclesiology: A critical assessment in the light of biblical and church teaching, Catholic University of Eastern Africa (CUEA), Nairobi.

Osmer, R.R., 1992, Teaching for faith: A guide for teachers of adult classes, Westminster/John Knox, Louisville.

Osmer, R.R., 1996, Confirmation: Presbyterian practices in ecumenical perspective, Geneva, Louisville.

Osmer, R.R., 2005, The teaching ministry of congregations, Westminster/John Knox, Louisville.

Pulpit and Pew Research Reports (n.d.), viewed n.d., from pulpitandpew@div.duke.edu.

Rendle, G. \& Mann, A., 2003, Holy conversations: Strategic planning as a spiritual practice for congregations, Alban, Bethesda.

Ritt, H., 1999, "'Sie waren ein Herz und eine Seele" (Apg 4,32)', in K. Baumgartner (ed.), Gemeinde Gestalten, pp. 15-34, Friedrich Pustet, Regensburg.

Rothauge, A.J., 1983, Sizing up a congregation for new member ministry, Episcopal Church Center, New York.

Roxburgh, A.J., 1979, The missionary congregation, leadership, and liminality, Trinity, Harrisburg.

Satterlee, C.A., 2005, When God speaks through change: Preaching in times of congregational transition, Alban, Herndon.

Schaller, L.E., 1981, Activating the passive church, Abingdon, Nashville.

Schaller, L.E., 1998, 44 questions for congregational self-appraisal, Abingdon, Nashville.

Schaller, L.E., 2001, What have we learned? Lessons for the church in the $21^{\text {st }}$ century, Abingdon, Nashville.

Schaller, L.E. 2003. From geography to affinity How congregations can learn from one another, Abingdon, Nashville.
Schippers, K.A., 1982, 'Werken aan de gewone gemeente, 1, 2, 3', Praktische Theologie 2, 96-105; Praktische Theologie 3, 181-192; Praktische Theologie 4, 211-224.

Schippers, K.A., 1983, 'Als de gemeente subjekt wordt ...', Praktische Theologie 10(3), 284-297.

Schippers, K.A., 1987, 'De aktuele betekenis van de ecclesiologie van Karl Barth voor de opbouw van de gemeente', Praktische Theologie 5, 509-519.

Schlottoff, B. (ed.), 1989, Gemeindeaufbau PROvokativ: Eine Pewspektive für die Kirche van übermorgen, SchriftenmissionsVerlag, Neukirchen-Vluyn.

Schnase, R., 2007, Five practices of fruitful congregations, Abingdon, Nashville.

Schreiter, R.J., 1985, Constructing local theologies, Orbis, Maryknoll.

Schütz, P., 1930, Zwischen Nil und Kaukasus, Chr Kaiser, Munich.

Schwarz, C.A., 1996, Natural church development: A guide to eight essential qualities of healthy churches, ChurchSmart Resources, Carol Stream.

Schwarz, C.A., 1999, Paradigm shift in the church: How natura church development can transform theological thinking, ChurchSmart Resources, Carol Stream.

Schwarz, C.A. \& Schalk, C., 1998, Natural church development: Implementation guide to, ChurchSmart Resources, Carol Stream.

Schwarz, F. \& Schwarz, C.A., 1984, Theologie des Gemeindeaufbaus, Aussaat, Neukirchen-Vluyn.

Shawchuck, N. \& Rath, G., 1994, Benchmarks of quality in the church: 21 ways to continuously improve the content of your ministry, Nashville, Abingdon.

Sider, R.J., Olson, P.N. \& Unruh, H.R., 2002, Churches that make a difference: Reaching your community with good news and good works, Baker, Grand Rapids.

Sjogren, S., 1993, Conspiracy of kindness, Vine Books, Ann Arbor.

Sjogren, S., 2002, The perfectly imperfect church: Redefining the "ideal" church, Group, Flagship Church Resources, Loveland.

Snyder, H.A., 1977, The community of the King, Inter-Varsity, Downers Grove.

Snyder, H.A., 2005, Radical renewal: The problem of wineskins today, Wipf \& Stock, Eugene.

Snyder, H.A. \& Runyon, D.V., 2002, Decoding the church: Mapping the DNA of Christ's body, Baker, Grand Rapids.

Stadelmann, H. (ed.), 1998, Baustene zur Erneuerung der Kirche: Gemeindeaufbau auf der Basis einer biblisch erneuerten Ekklesiologie, Brunnen, Giessen.

Sweazey, G.E., 1978, The church as evangelist, Harper \& Row, San Francisco.

Sweet, L. (ed.), 2003, The church in emerging culture: Five perspectives, Zondervan, Grand Rapids.

Sweet, L. (ed.), 2008, The church of the perfect storm, Abingdon, Nashville.

Toler, S. \& Nelson, A., 1999, The five-star church: Helping your church provide the highest level of service to God and his people, Regal Books, Ventura.

Tucker, G.L. Jr., 1982, A church planning questionnaire: Manual and discoveries from 100 churches, Grayson L. Tucker, Louisville.

Van Gelder, C., 2000, The essence of the church, Baker, Grand Rapids.

Van Ruler, A.A., 1969, Theologisch Werk I, Callenbach, Nijkerk.

Van Ruler, A.A., 1973, Theologisch Werk VI, Callenbach, Nijkerk.

Walters, T.P. (ed.), 1984, Handbook for parish evaluation, Paulist, New York.

Waltke, B.K. \& Fredricks, C.J., 2001, Genesis: A commentary, Zondervan, Grand Rapids.

Warner, R.S., 1994, 'The place of the congregation in the contemporary American religious configuration', in J.P. Wind \& J.W. Lewis (eds.), American congregations, vol. 2, New perspectives in the study of congregations, pp. 54-99, University of Chicago Press, Chicago. 
Wind, J.P. \& Lewis, J.W. (eds.), 1994, American congregations, vol. 2, New perspectives in the study of congregations, pp. 54-99, University of Chicago Press, Chicago.

Woolever, C. \& Bruce, D., 2004, Beyond the ordinary: 10 strengths of US congregations, Westminster John Knox, Louisville.

Woolever, C. \& Bruce, D., 2008, Places of promise: Finding strength in your co ngregation's location, Westminster John Knox, Louisville.

\section{REFERENCES TO QUESTIONNAIRES}

Ammermann (1997:371-380; 2005:4, 283-286)

Callahan (1987; 1990)

Carroll, Dudley and McKinney (1986:182-190)

Dick (2007:127-135)
Dudley and Ammermann (2002), with specific reference to their working notes at the end of each chapter ( $c f$. for example 2002:32,

53 , etc.)

Easum (2006:15-45)

Getz (1975:154 ff; 1984:317 ff)

Hendriks (2004)

Hopewell (1984)

Schaller (1981:66-69)

Schwarz (1996; 1998)

Toler and Nelson (1999:145-160)

Tucker (1982:111-120, 121-124)

Woolever and Bruce (2008:121-124) 